\title{
Brandtodinium gen. nov. and B. nutricula comb. Nov. (Dinophyceae), a dinoflagellate commonly found in symbiosis with polycystine radiolarians
}

\author{
Probert lan ${ }^{1,}{ }^{*}$, Siano Raffaele ${ }^{2}$, Poirier Clement ${ }^{3}$, Decelle Johan ${ }^{3}$, Biard Tristan ${ }^{3}$, Tuji Akihiro ${ }^{4}$, \\ Suzuki Noritoshi ${ }^{5}$, Not Fabrice ${ }^{3}$
}

1 UPMC, CNRS, FR2424, Roscoff Culture Collect,Stn Biol Roscoff, F-29682 Roscoff, France.

2 IFREMER, Ctr Brest, DYNECO Pelagos, F-29280 Plouzane, France.

3 UPMC, CNRS, UMR 7144, Stn Biol Roscoff, F-29682 Roscoff, France.

4 Natl Museum Nat \& Sci, Dept Bot, Tsukuba, Ibaraki 3050005, Japan.

5 Tohoku Univ, Grad Sch Sci, Inst Geol \& Paleontol, Sendai, Miyagi 9808578, Japan.

* Corresponding author : Ian Probert, email address : probert@sb-roscoff.fr

\begin{abstract}
:
Symbiotic interactions between pelagic hosts and microalgae have received little attention, although they are widespread in the photic layer of the world ocean, where they play a fundamental role in the ecology of the planktonic ecosystem. Polycystine radiolarians (including the orders Spumellaria, Collodaria and Nassellaria) are planktonic heterotrophic protists that are widely distributed and often abundant in the ocean. Many polycystines host symbiotic microalgae within their cytoplasm, mostly thought to be the dinoflagellate Scrippsiella nutricula, a species originally described by Karl Brandt in the late nineteenth century as Zooxanthella nutricula. The free-living stage of this dinoflagellate has never been characterized in terms of morphology and thecal plate tabulation. We examined morphological characters and sequenced conservative ribosomal markers of clonal cultures of the free-living stage of symbiotic dinoflagellates isolated from radiolarian hosts from the three polycystine orders. In addition, we sequenced symbiont genes directly from several polycystine-symbiont holobiont specimens from different oceanic regions. Thecal plate arrangement of the free-living stage does not match that of Scrippsiella or related genera, and LSU and SSU rDNA-based molecular phylogenies place these symbionts in a distinct clade within the Peridiniales. Both phylogenetic analyses and the comparison of morphological features of culture strains with those reported for other closely related species support the erection of a new genus that we name Brandtodinium gen. nov. and the recombination of S. nutricula as B. nutricula comb. nov.
\end{abstract}

Keywords : symbiosis, taxonomy, Scrippsiella, Peridiniales, Radiolaria, polycystines, dinoflagellate, Zooxanthella 


\section{Abbreviations}

$\begin{array}{ll}\text { ICBN } & \text { International Code for Botanical Nomenclature } \\ \text { ITS } & \text { internal transcribed spacer } \\ \text { LM } & \text { light microscopy } \\ \text { LSU } & \text { large subunit (ribosomal DNA) } \\ \text { ML } & \text { maximum likelihood } \\ \text { PCR } & \text { polymerase chain reaction } \\ \text { RCC } & \text { roscoff culture collection } \\ \text { SEM } & \text { scanning electron microscopy } \\ \text { SSU } & \text { small subunit (ribosomal DNA) }\end{array}$


Introduction

2 Mutualistic associations involving photosynthetic microalgae are common in both

3 benthic and pelagic ecosystems and are essential for establishing and maintaining the

4 structure of marine communities (Caron 2000). Symbiosis between corals and the

5 dinoflagellate genus Symbiodinium Freudenthal is fundamental for the survival and

6 ecological success of coral reef ecosystems. Members of the genus Symbiodinium

7 have been intensively studied with respect to their morphology and life cycle

8 (Freudenthal 1962; Fitt and Trench 1983; Trench and Blank 1987), and genetic

9 diversity (Coffroth and Santos 2005; Sampayo et al. 2009; LaJeunesse and Thornhill

10 2011; Stat et al. 2011). Studies on this coastal benthic symbiotic relationship

11 significantly increased when the coral-bleaching phenomenon was brought to global

12 attention and associated to increases in sea surface temperature, enhanced light

13 intensity, and ocean acidification (Hoegh-Guldberg et al. 2007).

14 Symbiotic interactions between pelagic hosts and microalgae have received less

15 attention, despite the fact that they are widespread in the photic layer of the world

16 ocean where they play a fundamental role in the ecology of the planktonic ecosystem

17 (Stoecker et al. 2009; Decelle et al. 2012). Recent studies have demonstrated that

18 dinoflagellate symbionts of Foraminifera belong to Pelagodinium Siano, Montresor,

19 Probert et de Vargas, a genus that is related to Symbiodinium within the order

20 Suessiales (Siano et al. 2010), and that Acantharia typically associate with members

21 of the prymnesiophyte genus Phaeocystsis Lagerheim (Decelle et al. 2012), although

22 one taxon, Acanthochiasma sp., can contain multiple symbiotic partners, including

23 distantly related dinoflagellates (from the genera Pelagodinium, Heterocapsa Stein,

24 Azadinium Elbrächter et Tillmann and Scrippsiella Balech ex Loeblich III) as well as

25 a haptophyte (Decelle et al. 2012b). 
1 Polycystine radiolarians (including the orders Spumellaria, Collodaria and

2 Nassellaria) are single-celled, heterotrophic, biomineralizing planktonic protists from

3 the Rhizaria lineage that are widely distributed in the ocean and are found throughout

4 the entire water column (Boltovskoy et al. 2010). Many polycystines host microalgae

5 within their cytoplasm (Anderson 1983). Cells containing photosynthetic microalgae

6 have been shown to survive for longer periods in nutrient-poor water than those that

7 do not have microalgal partners and the microalgae are therefore assumed to be

8 symbionts that play a nutritive role for the hosts (Anderson 1983).

9 Polycystines form associations with various dinoflagellate, prymnesiophyte and

10 prasinophyte partners (usually not at the same time), with dinoflagellates being the

11 most common symbiotic partners (Anderson 1976, 1983; Anderson et al. 1983). In the

12 late nineteenth century, Karl Brandt was the first to recognize that the "yellow cells"

13 within polycystines, actinian corals and hydrozoans were microalgae, which he

14 collectively described in the new genus Zooxanthella Brandt (Brandt 1881), although

15 they were not immediately recognized as dinoflagellates. Soon afterwards, the species

16 Z. nutricula Brandt was proposed for the symbiont of the collodarian polycystine

17 Collozoum inerme collected from the western Mediterranean Sea and it was stated in

18 the description that this species was presumably identical to the yellow cells of other

19 polycystines (Brandt 1882). The subsequent taxonomic history of this genus and

20 species have been very confused (see review by Blank \& and Trench 1986), and the

21 plural noun 'zooxanthellae' has persisted as a colloquialism used to describe marine

22 microalgal endosymbionts in general.

23 The symbionts of the 'by-the-wind sailor' hydrozoan jellyfish Velella velella were

24 reported to be similar to those of polycystines initially by Hovasse (1922), who

25 initially described the in hospite symbionts of Mediterranean $V$. velella as Endodinium 
1 chattoni Hovasse (E. chattonii under ICBN Art. 73). Taylor (1971) and Hollande and

2 Carré (1974) further characterized the in hospite stage of E. chattonii and the latter

3 authors proposed the reclassification of the polycystine symbionts (Z. nutricula) as E.

$4 \quad$ nutricola (Brandt) Hollande et Carré (E. nutricula under ICBN Art. 73), despite the

5 fact that Hovasse (1924) had in fact previously recombined E. chattonii as Z. chattonii

6 (Hovasse) Hovasse. Banaszak et al. (1993) isolated a culture of the symbiont of $V$.

7 velella from the Pacific, which they considered slightly different from E. chattonii

8 (larger cell size and presence of trichocysts in hospite and in culture). Based on SEM

9 observations of the morphology and arrangement of thecal plates in the motile stage,

10 Banaszak et al. (1993) classified their organism in the genus Scrippsiella as a new

11 species, S. velellae Banaszak, Iglesias-Prieto et Trench (a name later validated by

12 Trench 2000). These authors also transferred E. chattonii and E. nutricula to

13 Scrippsiella as $S$. chattonii (Hovasse) Banaszak, Iglesias-Prieto et Trench and $S$.

14 nutricula (Brandt) Banaszak, Iglesias-Prieto et Trench, respectively (Banaszak et al.

15 1993), but these names remain technically invalid because reference was not made to

16 the exact page of the basionym.

17 Using molecular methods, Gast and Caron (1996) found that the dinoflagellate

18 symbionts in six different polycystine species from the Sargasso Sea (the collodarians

19 Collozoum caudatum and Thalassicolla nucleata, three unidentified collodarian

20 species and the spumellarian Spongostaurus sp.) had identical SSU rDNA sequences

21 that they assigned to Scrippsiella nutricula. These molecular analyses indicate that

22 taxonomically divergent radiolarians can contain the same symbiotic dinoflagellate.

23 Since these analyses were conducted directly on symbionts extracted from the hosts

24 (i.e., not cultured), the morphology of the motile stage of the symbiotic algae assigned

25 to $S$. nutricula was not investigated, and has still never been reported. Gast and Caron 
1 (1996) also sequenced the SSU rDNA of the symbiont of $V$. velella from the Sargasso

2 Sea and found that the sequence was very similar to those of the radiolarian symbionts

3 (4 differences out of 1802 base pairs). They therefore also assigned this $V$. velella

4 symbiont to $S$. nutricula.

5 Here we examined the morphology and molecular phylogenetic position of clonal

6 cultures of the free-living stage of dinoflagellates isolated from several different

7 polycystine radiolarian hosts, including Collozoum, the taxon from which

8 Zooxanthella nutricula was originally described. In addition, we sequenced symbiont

9 genes directly from several polycystine-symbiont holobiont specimens (including

10 collodarian, spumellarian and nassellarian hosts) from different oceanic regions.

11 Accurate morpho-molecular characterization and taxonomic designation of symbionts

12 from the genus Symbiodinium has been key for studies of the ecology and functioning

13 of coral reef systems and is it is likewise likely to prove important for future studies

14 on the widespread pelagic symbiosis involving polycystine radiolarian hosts.

15

16 Material and Methods

17 Samples and culture isolation

18 The radiolarian specimens from which the holobiont sequences or cultures originated

19 were isolated from samples collected in 2010-2012 by net tows (20 to 150 micron

20 mesh size) in the bay of Villefranche-sur-Mer (France), off Sesoko Island, Okinawa

21 (Japan) and in the South Pacific Ocean during the Tara Oceans expedition (Table 1,

22 Supplementary Figs 1 and 2). The polycystines were first sorted from fresh net

23 samples under a binocular microscope, cleaned by successive transfers in sterile

24 seawater in Petri dishes, then left in an illuminated and temperature-regulated

25 incubator for several hours to self-clean. Individual clean specimens were then 
1 identified based on their morphology and imaged under an inverted microscope. Some

2 specimens were then transferred to guanidinium isothiocyanate (GITC) buffer for

3 direct DNA extraction from holobionts. The dinoflagellate cultures were obtained by

4 micropipette isolation of single symbiont cells released from live radiolarian

5 specimens that were microdissected under an inverted microscope. The resulting

6 monoclonal cultures were maintained in filter-sterilized seawater with K/2(-Tris, $-\mathrm{Si}$ )

7 medium supplements (Keller et al. 1987) at $22^{\circ} \mathrm{C}$ with an irradiance of $70-80 \mu \mathrm{mol}$

8 photons $\mathrm{m}^{-2} \mathrm{~s}^{-1}$ in a 12:12 light:dark regime. The cultures have been deposited in the

9 Roscoff Culture Collection (http://www.sb-roscoff.fr/Phyto/RCC). LM images of

10 radiolarian holobionts from which sequences / cultures were obtained are shown in

11 Supplementary Figures 1 and 2. Detailed information related to each of the samples

12 used in this study can be found in the RENKAN database at http://abims.sb-

13 roscoff.fr/renkan/.

14

15

16

17

18

19

20 21 with distilled water, dehydrated in an ethanol series $(25 \%, 50 \%, 75 \%, 95 \%, 100 \%)$,

22 and critical point dried. The filters were mounted on stubs, sputter coated with gold,

23 and examined with a FEI Quanta ${ }^{\text {TM }} 200$ SEM (FEI, Hillsboro, Oregon, USA)

24

25

\section{Microscopy preparations and observations}

Light micrographs of living cells were taken using a Zeiss Axiophot light microscope equipped with a Zeiss AxioCam digital camera system (Carl Zeiss, Oberkochen,

Germany). For scanning electron microscopy (SEM), dinoflagellate cells were fixed in $1 \%$ (v:v) formol for 2 hours at room temperature. Samples were then gently filtered onto $3 \mu \mathrm{m}$ pore-size Nucleopore polycarbonate filters (Pleasanton, CA, USA), washed 
1 Genomic DNA was extracted from exponentially growing cultures of the strains using

2 a NucleoSpin Plant II DNA extraction kit (Macherey-Nagel), or from holobionts

3 using the method described in De Vargas et al. (2002).

4 Partial nuclear LSU and SSU rDNA genes were PCR amplified using Phusion high-

5 fidelity DNA polymerase (Finnzymes) in a $25 \mu \mathrm{l}$ reaction volume and the following

6 thermocycler steps : an initial denaturation step at $98^{\circ} \mathrm{C}$ for $30 \mathrm{sec}$, followed by 35

7 cycles at $98^{\circ} \mathrm{C}$ for $10 \mathrm{sec}, 30 \mathrm{sec}$ at the temperature of semi-hybridization chosen for

8 each set of primers, and $30 \mathrm{sec}$ at $72^{\circ} \mathrm{C}$, with a final elongation step of $10 \mathrm{~min}$ at

$972^{\circ} \mathrm{C}$. The eukaryote primer set 63F (ACGCTT GTCTCAAAGATT) / 1818R

10 (ACGGAAACCTTGTTACGA) ( $\mathrm{Tm} 50^{\circ} \mathrm{C}$ ) (Lepere et al. 2011) was used to amplify

11 the SSU rDNA of the dinoflagellate cultures, whereas the dinoflagellate specific

12 primer set DIN464F (TAACAATACAGGGCATCCAT) / S69

13 (CCGTCADTTCCTTTRAGDTT) $\left(\mathrm{Tm} 53^{\circ} \mathrm{C}\right)$ was used to target the dinoflagellates in

14 the holobiont samples. The D1-D2 fragment of the LSU rDNA was amplified using

15 the dinoflagellate specific primers Ldino6 (MCC CGCTGAATTTAAGCATA) /

16 Ldino1 (AACGATTTGCAGGTCAGTACCGC) $\left(\mathrm{Tm} 55^{\circ} \mathrm{C}\right)$ from both cultures and

17 holobionts. PCR products were then sequenced at the GENOSCOPE (CEA, Evry,

18 France).

19 The sequences generated from the studied strains and holobionts (GenBank accession

20 numbers: XXXX KF557491 to KF557545 to XXXX) were aligned with other LSU

21 and SSU rDNA sequences from GenBank (release 194.0, February 2013) attributed to

22 Scrippsiella and related Peridiniales genera, as well as representatives of the

23 Suessiales as an outgroup. Alignments were generated using MUSCLE implemented

24 in Seaview v.4.0 (Gouy et al. 2010) with subsequent manual verification. The LSU 
rDNA data set contained 48 sequences ( 675 unambiguously aligned positions) and the SSU rDNA data set contained 57 sequences (652 unambiguously aligned positions).

Phylogenetic analyses were conducted with Maximum Likelihood (ML) and Bayesian

4 methods. The ML analysis was carried out using MEGA v. 5.1 (Tamura et al. 2011)

5 with the General Time Reversible (GTR) as the best model of nucleotide substitution

6 and considering a gamma distribution with a proportion of invariable sites (I) set at 5

7 by default. Bootstrap supports for the tree were obtained after 1000 replicates. The were conducted using Mr Bayes v.3.2.1 (Huelsenbeck and Ronquist 2001) using the

17 topologies.

18

19 Results

\section{Microscopy Observations}

21 In our culture conditions, our the clonal strains of polycystine symbionts tended to

22 contain a mixture of motile thecate cells and larger, irregularly-shaped non-motile

23 cells devoid of the typical features of motile cells (theca, cingulum, sulcus), the latter

24 more closely resembling the in hospite symbiotic state. The proportion of motile and

25 non-motile cells varied between strains and through growth cycles for each strain. The 
1 overall morphology and thecal plate pattern of motile cells was identical for several

2 different strains observed. The following descriptions and illustrations are based on

3 observations of strain VFR $1-1$ RCC 3387.

4 Cells are 10.5 to $15 \mu \mathrm{m}$ in length (average $13.1 \mu \mathrm{m}, \mathrm{n}=30$ ) and 9.1 to $11.2 \mu \mathrm{m}$ in

5 width (average $10.4 \mu \mathrm{m}, \mathrm{n}=30$ ). The epitheca is larger than the hypotheca. Observed

6 under LM, cells have a slightly convex conical epitheca with a well-pronounced

7 apical horn (Fig. 1A, 1B, 1D). The hypotheca is rounded (Fig. 1A, 1D). The nucleus

8 is large and occupies the center of the cells (Fig. 1B, 1D). One or two golden-yellow

9 chloroplasts are present around the cell periphery, sometimes appearing as a single

10 plastid bordering the cell periphery (Fig. 1D). One large circular pyrenoid (sometimes

11 two) is often visible in LM (Fig. 1A-D). No eyespot is visible in light microscopy.

12 Cells swim steadily in a straight line, rotating around the transapical axis. They

13 suddenly stop, change direction at different angles from the original path, often back-

14 tracking.

15 In SEM, the epitheca appears conical (Fig. 2A) to rounded (Fig. 2C), and the smaller

16 hypotheca is symmetrical and rounded in ventral (Fig. 2A) and dorsal (Fig. 2C) view.

17 The plate tabulation is Po, X, 4', 3a, 7", 5C, 4S, 5"', 1"'" (Figs 2A-E, 3A-D). The pore

18 plate $(\mathrm{Po})$ is circular and surrounded by a high collar and is connected to the first

19 apical plate by a long well-defined rectangular canal plate (X) (Figs 2A, 3A, 3C).

20 Three intercalary plates are interposed on the dorsal side of the cell between the apical

21 series and the second epithecal (precingular) series (Figs 2C-D, 3B-C). The first

22 intercalary plate (1a) is five-sided and borders only one of the apical plates (2'),

23 whereas the second and third intercalary plates (2a and $3 a$ ) are six-sided and both

24 border two apical plates (Figs 2C-D, 3C). The cingulum is located in the median

25 portion of the cell and descends slightly, displaced by approximately one third of its 
1 own width (Figs 2A, 2C, 3A-B). It is very wide and shallow and is constituted by a

2 single series of five rectangular plates, the first being much narrower than the others

3 (Fig. 2A-C, 2E, 3A-B). The sulcus is fairly shallow and narrows towards the antapical

4 end (Fig. 2A-B). The sulcal area comprises four plates (Fig. 2B, 3A). One of these

5 (Sd) forms a conspicuous flange extending over the median area of the sulcus,

6 partially covering the sulcal area (Fig. 2B). There appears to be a single plate (Ss)

7 beneath this flange (Fig. 2B). Flagella were not preserved in our SEM preparations. In

8 the hypotheca, a series of 5 trapezoid plates of similar size borders the cingulum. A

9 single six-sided antapical plate completes the hypothecal tabulation (Fig. 2E, 3D). The

10 cell surface is mostly smooth. We have never observed a peduncule in either LM or

11 SEM preparations.

12

13 Phylogenetic Analyses

14 PCR amplifications of DNA extracts from culture strains and uncultured holobionts

15 led to generation of 35 partial SSU rDNA $(\sim 650 \mathrm{bp})$ and 22 partial LSU rDNA $(\sim 675$

$16 \mathrm{bp})$ sequences of dinoflagellate symbionts from spumellarian, collodarian and

17 nassellarian hosts collected in the Mediterranean Sea and in the North and South

18 Pacific oceans (Table 1). For each gene the vast majority of these sequences were

19 identical (see below) and hence only a subset of 15 SSU rDNA and 10 LSU rDNA

20 sequences, representing a cross-section of host diversity, were included in datasets for

21 phylogenetic reconstructions. Phylogenetic analyses on the SSU and LSU rDNA

22 datasets demonstrated that all of our sequences grouped together in a distinct and

23 highly supported clade (hereafter called clade B) within the dinoflagellate order

24 Peridiniales (full ML and Bayesian statistical support; Figs. 4 and 5). In both SSU and

25 LSU rDNA phylogenies, this clade included two distinct sub-clades, B1 and B2, each 
1 containing sequences that are $100 \%$ identical irrespective of host taxon and oceanic

2 region. In our SSU rDNA phylogenetic tree (Fig. 4), sub-clade B1 included the

3 majority of symbiont sequences recovered in this study (including those from five

4 culture strains isolated from Collozoum colonies from the Mediterranean Sea and

5 Pacific Ocean), as well as published sequences that correspond to the symbionts of

6 five collodarians and one spumellarian collected in the Atlantic Ocean (Gast and

7 Caron 1996). Sub-clade B2 contained the sequences generated in the present study of

8 the symbionts of two collodarian holobionts as well as one published sequence

9 (U52357) of the symbiont of the jellyfish Velella velella (Gast and Caron 1996). In

10 both phylogenetic reconstructions, the monophyletic clade B containing the sequences

11 of polycystine symbionts was phylogenetically distinct from the well-supported clade

12 containing members of the genus Scrippsiella (including the holotype species $S$.

13 sweeneyae Loeblich III), but overall the phylogenetic relationships between clades

14 within the Peridiniales were not clearly resolved in our analyses. When sequences of

15

16

17

18

19

20

21

22

23 Discussion

24 Dinoflagellates that form symbiotic relationships with metazoan or protistan hosts are 25

members of the genus Bysmatrum, which have a plate tabulation pattern similar to

Scrippsiella-like peridinaleans (Table 2), were included in phylogenetic analyses, they

formed a distinct mono-generic clade which fell on a long branch that altered overall

tree topology (Supplementary Figure 3). In the SSU rDNA phylogeny (Figure 4), note

that the sequence labeled "uncultured alveolate from Nasselaria" (DQ916409) and the

two sequences labeled "Dinophyceae from Collodaria" (DQ116021 and DQ116022)

correspond to non-photosynthetic dinoflagellate parasites of Radiolaria (Gast 2006).

characterized by complex life cycles, with an alternation of symbiotic and free-living 
1 stages with considerable morphological and physiological differentiation between

2 them. Within the host cells, the symbionts are typically coccoid without flagella, and

3 the cingulum and sulcus are no longer apparent (Trench and Blank 1987). In the free-

4 living stage, cells tend to regain their original morphology (Freudenthal 1962; Spero

5 1987, Siano et al. 2010). Since the taxonomy of dinoflagellates is largely based on

6 comparison of the number, shape and arrangement of the thecal plates (or amphiesmal

7 vesicles in athecate species) that form the periplast of free-living motile cells, the

8 establishment of clonal cultures from symbionts extracted from their hosts is critical

9 for accurate taxonomic assignation.

10 The genus Zooxanthella was originally created to collectively describe the symbionts

11 of diverse hosts from the Mediterranean Sea, including polycystines, corals and

12 hydrozoans (Brandt 1881) and Z. nutricula was created to describe the symbionts of

13 the collodarian polycystine Collozoum inerme (Brandt 1882). The taxonomic history

14 of Zooxanthella has subsequently been confusing, with Z. nutricula being alternately

15 combined within Endodinium, Amphidinium Claperède et Lachmann (see review of

16 the nomenclatural history of endosymbiotic dinoflagellates by Blank and Trench,

17 1986) and most recently (albeit technically invalidly) within Scrippsiella (Banaszak et

18 al. 1993).

19 Our observations of the plate tabulation pattern of cultured motile cells of the free-

20 living stage of the dinoflagellate isolated from diverse polycystine hosts clearly show

21 that it is a member of the order Peridiniales (bilateral symmetry, cingulum only

22 slightly displaced, presence of Po and X plates, presence of 3 intercalary plates in the

23 epitheca) and that it should not be classified in the genus Scrippsiella, nor in the

24 related genera Calciodinellum, Bysmatrum, Pentapharsodinium, or Ensiculifera. All

25 of these latter genera are described as possessing 2 antapical plates, whereas the 
1 polycystine symbiont reported here possesses a single antapical plate (Table 2, Figs

2 2E and 3D). The presence of a single antapical plate is rare in the order Peridiniales,

3 occurring notably in a group of heterotrophic genera (Podolampas Stein,

4 Blepharocysta Ehrenberg, and Lissodinium Matzenauer) characterized by the absence

5 of both a cingulum and a depressed sulcus (Gómez et al. 2010) and a group of

6 heterotrophic taxa (Diplopsalis Bergh, Preperidinium Mangin, Boreadinium Dodge et

7 Hermes) characterized by having large lenticular-shaped cells. The radiolarian

8 symbionts are clearly morphologically and ecologically distinct from these other

9 peridinialeans with that have a single antapical plate.

10 The polycystine symbionts also differ from Scrippsiella and Bysmatrum (but not from

11 Pentapharsodinium and Ensiculifera) in possessing 5 (rather than 6) cingular plates.

12 The wing-like flange that covers the sulcal area has not been described in any of these

13 related genera. This structure resembles the peduncule cover plate (PC) of

14 heterotrophic dinoflagellates in the peridinialean family Pfiestereaceae Steidinger et

15 Burkholder emend. Litaker. Motile forms of members of the Pfiestereaceae feed

16 myzocytotically by means of a peduncule that emerges close to the flagella and that

17 can attach to microalgal prey or epidermal cells of live fish (e.g. Steidinger et al.

18 2006). We have not observed a peduncle in the taxon described here, but should it be

19 present, the Sd plate should rather be termed PC and the plate formula would become:

20 Po, X, 4', 3a, 7', 5c, ,3s, PC, 5',', 1','.

21 Comparison of morphological characters strongly supports a generic level separation

22 of the polycystine symbiont reported here from other described Peridiniales taxa, a

23 conclusion that is corroborated by phylogenetic analyses. In both SSU and LSU

24 phylogenies (Figs 4 and 5), the analyzed polycystine symbionts (including several

25 cultures isolated from Collozoum colonies) formed a well-supported clade within the 
1 Peridiniales, clearly distinct from Scrippsiella and related genera and distant from

2 other dinoflagellate taxa known to form symbiotic relationships such as the

3 suessialeans Symbiodinium and Pelagodinium.

4 In light of both morphological and genetic differences from existing genera, this taxon

5 should clearly be classified in a distinct genus. Although S. nutricula was previously

6 classified within the genus Endodinium, this genus was created to describe the

7 symbiont of Velella velella from the Mediterranean and there is sufficient doubt as to

8 whether these organisms are actually closely related (see below) to preclude

9 reinstatement of this combination, which in any case should be considered

10 synonymous with $Z$. nutricula. Strict adherence to nomenclatural rules would hence

11 dictate the use of the genus Zooxanthella for this species, but we agree with numerous

12 previous authors (e.g. Blank and Trench 1986; Trench and Blank 1987; Banaszak et

13 al. 1993) who have convincingly argued that Zooxanthella should be rejected as a

14 confusing name that has been widely applied to divergent taxa. We therefore propose

15 the erection of a new genus, which we name Brandtodinium Probert et Siano in

16 reference to Karl Brandt who first described this species (Brandt 1882), and the

17 transfer of $Z$. nutricula to this new genus as Brandtodinium nutriculum comb. nov.. In

18 the absence of a holotype, not provided in the original description of the species, we

19 designate Fig. 2, SEM illustrations of plate tabulation of the motile stage of the

20 culture strain VFR1-1CC3387 of this species, as the neotype for the species.

21 Whereas the generic level distinction of Brandtodinium from other peridinialeans is

22 obvious, the relationship of this genus to other genera within the Peridiniales is not

23 clear. In terms of overall morphology of the motile stage (e.g. cell size and shape,

24 plate tabulation), Brandtodinium has several features in common with members of the

25 Calciodinellaceae Taylor, a family that includes Scrippsiella. The Calciodinellaceae, 
1 however, are characterized by the production of calcified resting cysts, a feature that

2 we have not observed in Brandtodinium. As discussed above, Brandtodinium also has

3 certain morphological similarities with members of other groups such as the

4 Pfiestereaceae. An unexpectedly close genetic relationship between B. nutriculum (as

5 Z. nutricula) and a small group of taxa in which photosynthesis takes place by a

6 tertiary endosymbiont derived from a diatom (Horiguchi and Pienaar 1994), the

7 'dinotoms' (Imanian et al. 2011), was recently reported (Gottschling and McLean

8 2013). These investigators employed a 'maximal taxon sample' approach by inferring

9 relationships based on a concatenated SSU, LSU and ITS rDNA sequence alignment

10 irrespective of whether all of these sequences were available for the taxa included (i.e.

11 an alignment with significant gaps). Our individual SSU and LSU phylogenies do not

12 recover this relationship. The present study provides strong evidence from two highly

13 conserved phylogenetic markers (SSU and LSU rDNA) to support the conclusion

14 from our observations of the morphology of free-living cells that Brandtodinium is a

15 taxonomically distinct genus within the Peridiniales. We chose not to employ an

16 approach comparable to that of Gottschling and McLean (2013) because in-depth

17 assessment of evolutionary and phylogenetic relationships between Brandtodinium

18 and other members of the order Peridiniales goes beyond the scope of our research.

19 We nevertheless provide evidence that Brandtodinium is distinct from the dinotom

20 genera (Durinskia Carty et Cox, Galeidinium Tamura et Horiguchi, Kryptoperidinium

21 Lindemann, and some species currently assigned to Peridiniopsis Lemmermann or

22 Peridinium Ehrenberg) on the basis of morphological criteria, notably because

23 dinotom genera all have 2 antapical plates whereas $B$. nutriculum possesses a single

24 antapical plate, but also because the characteristic highly visible eyespot of dinotoms

25 is absent in B. nutriculum. 
1 Banaszak et al. (1993) described the dinoflagellate symbiont of the jellyfish Velella

2 velella from the Pacific as Scrippsiella velellae and also (albeit invalidly) transferred

3 Endodinium (=Zooxanthella) chattonii, the symbiont of Mediterranean $V$. velella, to

4 Scrippsiella, as $S$. chattonii. These authors gave the thecal plate formula for $S$.

5 velellae as pp (=Po, X), 4', 3a, 7’', 5c, 3s, 5',', 2’,', , which corresponds neither to

6 that of Scrippsiella nor to that of Brandtodinium (Table 2). The spine-like

7 protuberance on the first cingular plate illustrated in Figure 11 (page 520) of

8 Banaszak et al. (1993) is a characteristic feature of the genus Ensiculifera, to which

9 we believe this species should have been assigned. However, the SEM images

10 illustrated in Banaszak et al. (1993) do not permit verification of whether this

11 organism really has 3 sulcal plates (as stated in the description), rather than 5 , as

12 diagnostic for members of the genus Ensiculifera. It could also be inferred that $S$.

13 chattonii, the symbiont of Mediterranean $V$. velella, might also be transferred to

14 Ensiculifera, but unfortunately no morphological data has ever been provided for the

15 free-living stage of this taxon. It is noteworthy that the only existing sequence (SSU

16 rDNA) of a symbiont of $V$. velella (from the Sargasso Sea, Atlantic Ocean) produced

17 by Gast and Caron (1996) falls within our Brandtodinium clade, in the sub-clade B2

18 composed of three identical sequences, two of which we generated from Pacific

19 polycystine holobionts. This sub-clade is distinct from the sub-clade B1 formed by the

20 group of identical sequences from all of our Pacific (South and North) and

21 Mediterranean culture strains of B. nutriculum isolated from polycystines, from

22 several Pacific polycystine holobionts that we sequenced, and from the Sargasso Sea

23 polycystine symbionts sequenced by Gast and Caron (1996). Gast and Caron (1996)

24 did not observe the morphology of the dinoflagellate symbionts of Sargasso Sea $V$.

25 velella that they sequenced, but we predict that they would have plate tabulation 
1 consistent with our description of Brandtodinium. If this were the case, it would mean

2 that $V$. velella is capable of forming symbiotic associations with different

3 dinoflagellate genera (Brandtodinium and Scrippsiella (or Ensiculifera)), possibly

4 with a biogeographical pattern (Brandtodinium in the Atlantic and possibly

5 Mediterranean, Scrippsiella (or Ensiculifera) in the Pacific). The capacity of hosts to

6 form associations with different symbionts has already been observed for other

7 pelagic organisms (Siano et al. 2010; Decelle et al. 2012b). A comparison of genetic

8 sequences from morphologically characterized cultured $V$. velella symbionts from the

9 Pacific Ocean, Sargasso Sea and Mediterranean Sea could be helpful in establishing

10 the validity of historical descriptions of these symbionts and their relationship to $B$.

11 nutriculum.

12 Brandtodinium has been found (in this and previous studies) in association with

13 diverse polycystine radiolarian hosts from the North and South Pacific Ocean,

14 Sargasso Sea, and Mediterranean Sea. In light of the abundance of symbiotic

15 polycystines in the world ocean, Brandtodinium likely plays a key ecological role in

16 primary and secondary production at a global scale. Putting aside associations with

17 parasitic alveolates (Gast 2006; Bråte et al. 20121) that can be considered as a form of

18 symbiosis, all Collodaria investigated so far harbor only Brandtodinium species as

19 symbionts. At present, Brandtodinium is the only symbiont identified for Nassellaria,

20 but information for this radiolarian group remains extremely scarce. Brandtodinium

21 has now been found in association with numerous spumellarian hosts, but unlike the

22 other polycystine lineages, other types of (non-dinoflagellate) microalgal and

23 cyanobacterial symbionts have also been reported for this group (Anderson 1983;

24 Gast and Caron 2001; Yuasa et al. 2005). With Brandtodinium also probably found in

25 symbiosis with jellyfish, it is clear that Brandtodinium, like the suessialean 
1 dinoflagellates Pelagodinium and Symbiodinium, is a generalist symbiont. In this

2 context it is interesting to note that the known genetic diversity (in terms of SSU and

3 LSU rDNA sequences) of Brandtodinium and Pelagodinium, both of which form

4 symbiotic relationships with planktonic hosts, is relatively low (2 clades described

5 within each of these genera) compared to that of Symbiodinium (9 divergent clades

6 and multiple sub-clades, Stat et al. 2008; Pochon and Gates 2010) that is

7 predominately found in association with benthic host organisms. This apparent trend

8 might be explained by the relatively low number of studies on symbiosis in the

9 pelagic realm ${ }_{2}$ but might also be real and reflect inherent differences between life and

10 symbiotic processes in planktonic and benthic ecosystems (Decelle 2013).

11

12 Taxonomic appendix

13 Brandtodinium Probert et Siano gen. nov.

14 Diagnosis: Photosynthetic dinoflagellate. Motile cells covered by 6 series of thecal

15 plates: 3 in the epitheca, 2 in the hypotheca (including single antapical plate), and 1 in

16 the cingulum. One transverse and one longitudinal flagellum. Large nucleus located in

17 central part of cell. One or two peripheral chloroplasts, golden-yellow in color. One or

18 two large circular pyrenoids.

19 Type species: Brandtodinium nutriculum (Brandt) Probert et Siano comb. nov.

20 Etymology: the genus name for this dinoflagellate (= dinos) derives from Karl Brandt

21 who first described Zooxanthella in 1882.

22

23 Brandtodinium nutriculum (Brandt) Probert et Siano comb. nov.

24 Basionym: Zooxanthella nutricula Brandt in Brandt (1882): 140 
1 Synonyms: Endodinium nutricula (Brandt) Hollande et Carré in Holland and Carré

2 (1974); Scrippsiella nutricula (Brandt) Banaszak, Iglesias-Prieto et Trench in

3 Banaszak et al. (1993).

$4 \quad$ Neotype : Fig. 2 in this publication.

5 Diagnosis: Plate tabulation: Po, X, 4', 3a, 7’, 5c, 4s, 5',', 1',,'. Epitheca larger than

6 hypotheca. Epitheca convex conical with well-pronounced apical horn. Hypotheca

7 rounded. Wide and shallow cingulum located in the median portion of the cell,

8 displaced by a small fraction of its own width. Sulcal area with 4 plates, one of which

9 forms a wing-like flange over the median part of the sulcus. Single antapical plate.

10 Cells on average $13.1 \mu \mathrm{m}$ in length by $10.4 \mu \mathrm{m}$ in width. Symbiont of polycystine

11 radiolarians.

12

Type locality: Bay of Villefranche sur Mer (France), Western Mediterranean Sea Authentic culture strain: RCC3387 in the Roscoff Culture Collection.

16 Acknowledgements

17 We thank staff (in particular John Dolan and Sophie Marro) of the Laboratoire

18 d'Océanographie de Villefranche-sur-Mer (UPMC-CNRS) and of the Sesoko Marine

19 Station (University of Ryukyus) as well as the Tara Oceans Expedition

20 (doi:10.1371/journal.pbio.1001177) for providing sampling facilities. We thank

21 Nicolas Gayet of the Laboratoire Environnement Profond (PDG-REM-EEP-LEP) of

22 Ifremer Centre de Brest for his technical support for electron microscopy analyses and

23 Julien Quéré of the Dyneco/Pelagos laboratory (PDG-ODE-DYNECO-PELAGOS)

24 for cultivating stains at Ifremer. This research was supported by a JST-CNRS

25 exchange program to F.N and N.S., the "Bibliothèque du Vivant" network funded by 
1 the CNRS, the Muséum National d'Histoire Naturelle, the INRA and the CEA (Centre

2 National de Séquençage), the EU FP7 projects ASSEMBLE (grant agreement

3 227799) and MACUMBA, and the French Investissements d'Avenir project EMBRC-

4 France.

5

6

7 References

8

9 Anderson, O.R. 1976. Ultrastructure of a colonial radiolarian Collozoum inerme and a

10 cytochemical determination of the role of its zooxanthellae. Tissue and Cell 8:195-

11208.

12

13 Anderson, O.R. 1983. Radiolaria. Springer-Verlag, New York, 363pp.

14

15 Anderson, O.R., Swanberg, N.R. \& Bennet P. 1983 Assimilation of symbiont-derived

16 photosynthates in some solitary and colonial radiolaria. Mar. Biol. 77:265-69.

17

18 Banaszak, A.T., Iglesias-Prieto, R. \& Trench, R.K. 1993. Scrippsiella velellae sp.

19 nov. (Peridiniales) and Gloeodinium viscum sp. nov (Phytodiniales), dinoflagellate

20 symbionts of hydrozoans (Cnidaria). J. Phycol. 29:517-28.

21

22 Blank, R.J. \& Trench, R.K. 1986. Nomenclature of endosymbiotic dinoflagellates.

23 Taxon 35:286-94.

24 
1 Boltovskoy, D., King, S.A., Takahashi, K. \& Bjorklund, K. 2010. World Atlas of

2 Distribution of Recent Polycystina (Radiolaria). Paleontologia Electronica 13(3)

3 18A:230pp.

4

5 Brandt, K. 1881. Ueber das Zusammenleben von Thieren und Algen. Verh. Physiol.

6 Ges. Berlin 1881-1882:22-26

7

8 Brandt, K. 1882. Ueber die morphologische und physiologische Bedeutung des

9 Chlorophylls bei Thieren. Mittheil. Zool. Stat. Neapel. 4:191-302.

10

11 Bråte, J., Krabberød, A.K., Dolven, J.K., Ose, R.F., Kristensen, T., Bjørklund, K.R. \&

12

13

14

15 Caron, D. 2000. Symbiosis and mixotrophy among pelagic microorganisms. In

16 Kirchman, D.L. (ed) Microbial Ecology of the Oceans. Wiley-Liss Inc., New York,

17 pp 495-523.

18

19 Coffroth, M.A. \& Santos, S.R. 2005. Invited Review: Genetic diversity of symbiotic 20 dinoflagellates in the genus Symbiodinium. Protist 156:19-34.

21

22 Decelle, J., Probert, I., Bittner, L., Desdevises, Y., Colin, S., de Vargas, C., Gali, M., 23 Simo, R. \& Not, F. 2012. An original mode of symbiosis in open ocean plankton.

24 Proc. Natl. Acad. Sci. U.S.A. 109:18000-5.

25 
1 Decelle, J., Siano, R., Probert, I., Poirier, C. \& Not, F. 2012b. Multiple microalgal

2 partners in symbiosis with the Acantharia Acanthochiasma sp. (Radiolaria). Symbiosis

$3 \quad 58: 233-44$.

4

5 Decelle, J. 2013. New perspectives on the functioning and evolution of

6 photosymbiosis in plankton: Mutualism or parasitism? Communicative \& Integrative

$7 \quad$ Biology 6(4): e24560.

8

9 De Vargas, C., Bonzon, M., Rees, N.W., Pawlowski, J. \& Zaninetti, L. 2002. A

10 molecular approach to biodiversity and biogeography in the planktonic foraminifer

11 Globigerinella siphonifera (d'Orbigny). Mar. Micropal. 45:101-16.

12

13 Fitt, W.K. \& Trench, R.K. 1983. The relation of diel patterns of cell division to diel

14 patterns of motility in the symbiotic dinoflagellate Symbiodinium microadriaticum

15 Freudenthal in culture. New Phytol. 94:421-32.

16

17 Freudenthal, H.D. 1962. Symbiodinium gen. nov. and Symbiodinium microadriaticum

18 sp. nov., a zooxanthella: Taxonomy, life cycle and morphology. J. Protozool. 9:45-52.

19

20 Gast, R.J. \& Caron, D.A. 1996. Molecular phylogeny of symbiotic dinoflagellates

21 from planktonic foraminifera and radiolaria. Mol. Biol. Evol. 13:1192-97.

22

23 Gast, R.J. \& Caron, D.A. 2001. Photosymbiotic associations in planktonic

24 foraminifera and radiolaria. Hydrobiologia 461:1-7.

25 


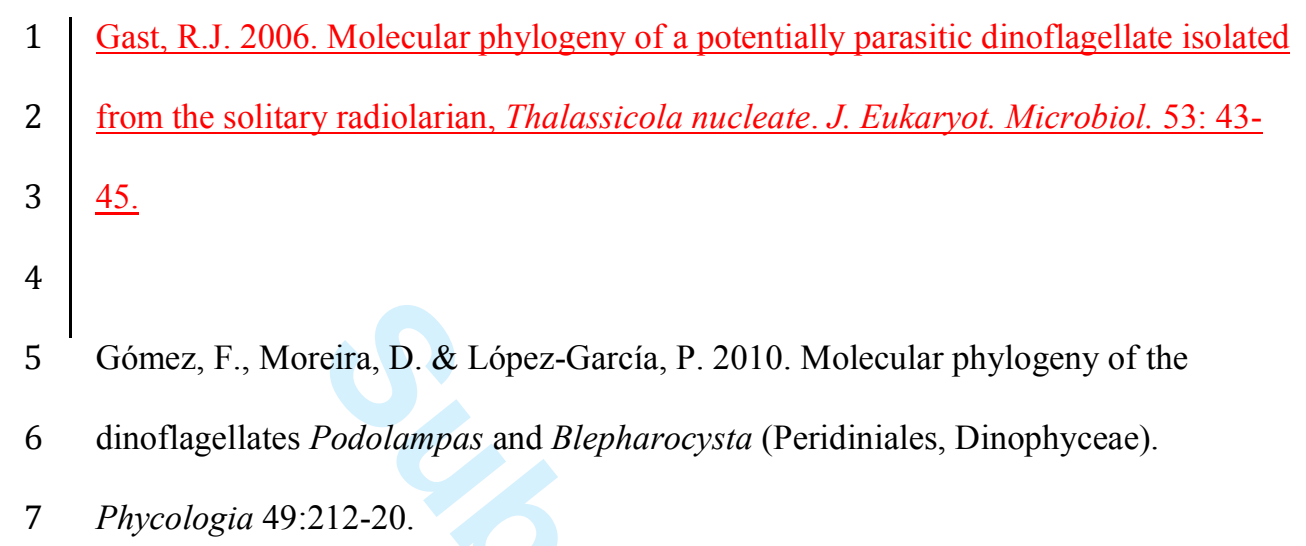

9 Gottschling, M. \& McLean, T.I. 2013. New home for tiny symbionts: Dinophytes 10 determined as Zooxanthella are Peridiniales and distantly related to Symbiodinium.

11 Mol. Phylogenet. Evol. 67:217-22.

12

13 Gouy, M., Guindon, S. \& Gascuel, O. 2010. SeaView version 4: a multiplatform 14 graphical user interface for sequence alignment and phylogenetic tree building. Mol. 15 Biol. Evol. 27:221-24.

16

17 Hoegh-Guldberg, O., Mumby, P.J., Hooten, A.J., Steneck, R.S., Greenfield, P., 18 Gomez, E., Harvell, C.D., Sale, P.F., Edwards, A.J., Caldeira, K., Knowlton, N., 19 Eakin, C.M., Iglesias-Prieto, R., Muthiga, N., Bradbury, R.H., Dubi, A. \& Hatziolos, 20 M.E. 2007. Coral reefs under rapid climate change and ocean acidification. Science $21 \quad 318: 1737-42$.

22

23 Hollande, A. \& Carré, D. 1974. Les Xanthelles des Radiolaires Sphaerocollides, des 24 Acanthaires et de Velella velella: infrastructure - cytochimie - taxonomie.

25 Protistologica 10: 573-601. 
2 Horiguchi, T. \& Pienaar, R.N. 1994. Ultrastructure of a new marine sand-dwelling

3 dinoflagellate, Gymnodinium quadrilobatum sp. nov. (Dinophyceae) with special

4 reference to its endosymbiotic alga. European J. Phycol. 29: 237-45.

5

6 Hovasse, R. 1922. Endodinium chattoni (nov. gen. et sp.). Son cycle de multiplication

7 endogène. Variation du nombre de ses chromosomes. Compte Rendu Hebdomadaire

8 des Séances de l'Académie des Sciences, Paris 87:845-46.

9

10 Hovasse, R. 1924. "Zooxanthella chattonii" (Endodinium chattonii). Bull. Biol. Fr.

11 Belg. 58:34-38.

12

13 Huelsenbeck, J.P. \& Ronquist, F. 2001. MRBAYES: Bayesian inference of

14 phylogenetic trees. Bioinformatics 17:754-55.

15

16 Imanian, B., Pombert, J.-F. \& Keeling, P.J. 2011. The complete plastid genomes of

17 the two 'dinotoms' Durinskia baltica and Kryptoperidinium foliaceum. PLoS One 5:

$18 \mathrm{e} 10711$.

19

20 Keller, M.D., Selvin, R.C., Claus, W. \& Guillard, R.R.L. 1987. Media for the culture

21 of oceanic ultraphytoplankton. J. Phycol. 23:633-38.

22

23 LaJeunesse, T.C. \& Thornhill D.J. 2011. Improved resolution of reef-coral

24 endosymbiont (Symbiodinium) species diversity, ecology, and evolution through psbA

25 non-coding region genotyping. PLoS One 6:e29013 
2 Lepere, C., Demura, M., Kawachi, M., Romac, S., Probert I. \& Vaulot D. 2011.

3 Whole Genome Amplification (WGA) of marine photosynthetic eukaryote

4 populations. FEMS Microbiological Ecology 76: 513-23.

5

6 Pochon, X. \& Gates, R.D. 2010. A new Symbiodinium clade (Dinophyceae) from

7 soritid foraminifera in Hawai'i. Molecular Phylogenetics and Evolution 56:492-97.

8

9 Rambaut, A. 2010. FigTree 1.3.1. [http://tree.bio.ed.ac.uk/software/figtree/].

10

11 Sampayo, E.M., Dove, S. \& Lajeunesse, T.C. 2009. Cohesive molecular genetic data

12 delineate species diversity in the dinoflagellate genus Symbiodinium. Mol. Ecol.

$13 \quad 18: 500-519$.

14

15 Siano, R., Montresor, M., Probert, I., Not, F., de Vargas, C. 2010. Pelagodinium gen.

16 nov. and $P$. beii comb. nov., a dinoflagellate symbiont of planktonic foraminifera.

17 Protist 161: 385-99.

18

19 Spero, H.J. 1987. Symbiosis in the planktonic foraminifer, Orbulina universa, and the

20 isolation of its symbiotic dinoflagellate, Gymnodinium béii sp. nov.. J. Phycol.

$21 \quad 23: 307-17$

22

23 Stat, M., Loh, W.K.W., Hoegh-Guldberg, O. \& Carter D.A. 2008. Symbiont

24 acquisition strategy drives host-symbiont associations in the southern Great Barrier

25 Reef. Coral Reefs 27:763-72. 
2 Stat, M., Bird, C.E., Pochon, X., Chasqui, L., Chauka, L.J., Concepcion, G.T., Logan,

3 D., Takabayashi, M., Toonen, R.J. \& Gates, R.D. 2011. Variation in Symbiodinium

4 ITS2 Sequence Assemblages among Coral Colonies. PLoS ONE 6:e15854.

5

6 Steidinger, K.A., Landsberg, J.H., Mason, P.L., Vogelbein, W.K., Tester, P.A. \&

7 Litaker, R.W. 2006. Cryptoperidiniopsis brodyi gen. et sp. nov. (Dinophyceae), a

8 small lightly armored dinoflagellate in the Pfiesteriaceae. J. Phycol. 42: 951-61.

9

10 Stoecker, D.K., Johnson, M.D., de Vargas, C. \& Not, F. 2009. Acquired phototrophy

11 in aquatic protists. Aquat. Microb. Ecol. 57:279-310.

12

13 Tamura, K., Peterson, D., Peterson, N., Stecher, G., Nei, M. \& Kumar, S. 2011.

14 MEGA5: Molecular Evolutionary Genetics Analysis using Maximum Likelihood,

15 Evolutionary Distance, and Maximum Parsimony Methods. Mol. Biol. Evol. 28:27311639.

17

18 Taylor, D.L. 1971. Ultrastructure of the "zooxanthellae" Endodinium chattonii in situ.

19 J. Mar. Biol. Ass. U.K. 51:227-34.

20

21 Trench, R. 2000. Validation of some currently used invalid names of dinoflagellates

22 (Note). J. Phycol. 36:972.

23

24 Trench, R.K. \& Blank, R.J. 1987. Symbiodinium microadriaticum Freudenthal; S.

25 goreauii sp. nov; S. kawagutii sp. nov. and S. pilosum sp. nov.: gymnodinioid 
1 dinoflagellate symbionts of marine invertebrates. J. Phycol. 23:469-81.

2

3 Yuasa, T., Takahashi, O., Honda, D. \& Mayama, S. 2005. Phylogenetic analyses of

4 the polycystine Radiolaria based on the 18s rDNA sequences of the Spumellarida and

5 the Nassellarida. European J. Protistology 41:287-98.

6 
Table 1. List of specimens used to obtain symbiont sequences_images of host cells are shown in Supplementary Figures 1 and 2).

\begin{tabular}{|c|c|c|c|c|c|}
\hline Host ID & Host taxonomy & Sampling site & $\begin{array}{l}\text { Strain } \\
\text { code }\end{array}$ & $\begin{array}{l}18 S \underline{S S U} \\
\text { rDNA } \\
\text { GenBank aee } \\
\text { \#accession } \\
\underline{\text { number }}\end{array}$ & $\begin{array}{l}28 S-\underline{L S U} \text { rDNA } \\
\text { GenBank ace } \\
\text { \#accession } \\
\underline{\text { number }}\end{array}$ \\
\hline \multicolumn{6}{|c|}{ Holobionts } \\
\hline PAC1 & $\begin{array}{l}\text { Collodaria } \\
\text { (solitary) }\end{array}$ & $\begin{array}{l}\text { South Pacific } \\
21^{\circ} 17.462 \mathrm{~S}, 105^{\circ} 9.476 \mathrm{~W}\end{array}$ & n.a. & $\begin{array}{l}\text { XXXXXxxKF5 } \\
57503\end{array}$ & $\begin{array}{l}\text { KF557534XXXK } \\
\text { \#\#K }\end{array}$ \\
\hline PAC2 & $\begin{array}{l}\text { Collodaria } \\
\text { (colony) }\end{array}$ & $\begin{array}{l}\text { South Pacific } \\
21^{\circ} 17.462 \mathrm{~S}, 105^{\circ} 9.476 \mathrm{~W}\end{array}$ & n.a. & $\begin{array}{l}\text { KF557504xx } \\
\operatorname{xxxxx}\end{array}$ & n.a. \\
\hline PAC3 & $\begin{array}{l}\text { Collodaria } \\
\text { (solitary) }\end{array}$ & $\begin{array}{l}\text { South Pacific } \\
23^{\circ} 42.949 \mathrm{~S}, 107^{\circ} 20.141 \mathrm{~W}\end{array}$ & n.a. & $\begin{array}{l}\text { KF557505xx } \\
\text { xxxxx }\end{array}$ & 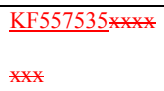 \\
\hline PAC4 & $\begin{array}{l}\text { Collodaria } \\
\text { (solitary) }\end{array}$ & $\begin{array}{l}\text { South Pacific } \\
23^{\circ} 42.949 \mathrm{~S}, 107^{\circ} 20.141 \mathrm{~W}\end{array}$ & n.a. & $\begin{array}{l}\text { KF557506** } \\
\text { Xxxxx }\end{array}$ & $\begin{array}{l}\text { KF557536* } \ldots \text { KK } \\
\text { XXX }\end{array}$ \\
\hline PAC6 & $\begin{array}{l}\text { Collodaria } \\
\text { (solitary) }\end{array}$ & $\begin{array}{l}\text { South Pacific } \\
24^{\circ} 48.085 \mathrm{~S}, 110^{\circ} 33.307 \mathrm{~W}\end{array}$ & n.a. & $\begin{array}{l}\text { KF557507xx } \\
\text { xxxxx }\end{array}$ & n.a. \\
\hline PAC7 & $\begin{array}{l}\text { Collodaria } \\
\text { (colony) }\end{array}$ & $\begin{array}{l}\text { South Pacific } \\
24^{\circ} 48.085 \mathrm{~S}, 110^{\circ} 33.307 \mathrm{~W}\end{array}$ & n.a. & $\begin{array}{l}\text { KF557508xx } \\
\text { xxxxx }\end{array}$ & n.a. \\
\hline PAC8 & $\begin{array}{l}\text { Collodaria } \\
\text { (colony) }\end{array}$ & $\begin{array}{l}\text { South Pacific } \\
24^{\circ} 48.085 \mathrm{~S}, 110^{\circ} 33.307 \mathrm{~W}\end{array}$ & n.a. & n.a. & $\begin{array}{l}\text { KF557537 XXXx } \\
\text { Xxx }\end{array}$ \\
\hline PAC 9 & $\begin{array}{l}\text { Collodaria } \\
\text { (colony) }\end{array}$ & $\begin{array}{l}\text { South Pacific } \\
24^{\circ} 48.085 \mathrm{~S}, 110^{\circ} 33.307 \mathrm{~W}\end{array}$ & n.a. & $\begin{array}{l}\text { KF557509xx } \\
\text { xxxxx }\end{array}$ & $\begin{array}{l}\text { KF557538 } \mathrm{xxxx} \\
\text { Xxx }\end{array}$ \\
\hline $\mathrm{PAC} 10$ & $\begin{array}{l}\text { Collodaria } \\
\text { (solitary) }\end{array}$ & $\begin{array}{l}\text { South Pacific } \\
24^{\circ} 48.085 \mathrm{~S}, 110^{\circ} 33.307 \mathrm{~W}\end{array}$ & n.a. & $\begin{array}{l}\text { KF557510** } \\
\text { XXXXX }\end{array}$ & n.a. \\
\hline PAC11 & $\begin{array}{l}\text { Collodaria } \\
\text { (solitary) }\end{array}$ & $\begin{array}{l}\text { South Pacific } \\
24^{\circ} 23.025 \mathrm{~S}, 113^{\circ} 58.068 \mathrm{~W}\end{array}$ & n.a. & $\begin{array}{l}\text { KF557511 XX } \\
\text { xxxxx }\end{array}$ & $\begin{array}{l}\text { KF557539:XXXX } \\
\text { XXx }\end{array}$ \\
\hline PAC14 & $\begin{array}{l}\text { Collodaria } \\
\text { (solitary) }\end{array}$ & $\begin{array}{l}\text { South Pacific } \\
24^{\circ} 23.025 \mathrm{~S}, 113^{\circ} 58.068 \mathrm{~W}\end{array}$ & n.a. & $\begin{array}{l}\text { KF557512xx } \\
x x x x x\end{array}$ & $\begin{array}{l}\text { KF557540xXXX } \\
\text { XXX }\end{array}$ \\
\hline PAC15 & $\begin{array}{l}\text { Collodaria } \\
\text { (solitary) }\end{array}$ & $\begin{array}{l}\text { South Pacific } \\
24^{\circ} 23.025 \mathrm{~S}, 113^{\circ} 58.068 \mathrm{~W}\end{array}$ & n.a. & $\begin{array}{l}\text { KF557513xx } \\
\operatorname{xxxxx}\end{array}$ & xxxxxxxn.a. \\
\hline PAC16 & $\begin{array}{l}\text { Collodaria } \\
\text { (colony) }\end{array}$ & $\begin{array}{l}\text { South Pacific } \\
24^{\circ} 23.025 \mathrm{~S}, 113^{\circ} 58.068 \mathrm{~W}\end{array}$ & n.a. & $\begin{array}{l}\text { KF557514X* } \\
\underset{x x x x x}{ }\end{array}$ & n.a. \\
\hline PAC17 & Collodaria & South Pacific & n.a. & KF557515x & KF557541×xXX \\
\hline
\end{tabular}




\begin{tabular}{|c|c|c|c|c|c|}
\hline & (colony) & $23^{\circ} 42.289 \mathrm{~S}, 131^{\circ} 12.744 \mathrm{~W}$ & & XXXXX & XXX \\
\hline$\overline{P A C 19}$ & $\begin{array}{l}\text { Collodaria } \\
\text { (colony) }\end{array}$ & $\begin{array}{l}\text { South Pacific } \\
23^{\circ} 42.289 \mathrm{~S}, 131^{\circ} 12.744 \mathrm{~W}\end{array}$ & n.a. & $\begin{array}{l}\text { KF557516xx } \\
\text { xxxxx }\end{array}$ & $\begin{array}{l}\text { KF557542*XXX } \\
\text { XXX }\end{array}$ \\
\hline PAC21 & $\begin{array}{l}\text { Collodaria } \\
\text { (colony) }\end{array}$ & $\begin{array}{l}\text { South Pacific } \\
23^{\circ} 42.289 \mathrm{~S}, 131^{\circ} 12.744 \mathrm{~W}\end{array}$ & n.a. & $\begin{array}{l}\text { KF557517 Xx } \\
\text { xxxxx }\end{array}$ & $\begin{array}{l}\text { KF557543*XXK } \\
\text { XXK }\end{array}$ \\
\hline$\overline{\mathrm{PAC} 22}$ & $\begin{array}{l}\text { Collodaria } \\
\text { (colony) }\end{array}$ & $\begin{array}{l}\text { South Pacific } \\
23^{\circ} 42.289 \mathrm{~S}, 131^{\circ} 12.744 \mathrm{~W}\end{array}$ & n.a. & $\begin{array}{l}\text { KF557518XX } \\
\text { XXXXX }\end{array}$ & $\begin{array}{l}\text { KF557544XXXX } \\
\text { XXX }\end{array}$ \\
\hline PAC24 & $\begin{array}{l}\text { Collodaria } \\
\text { (colony) }\end{array}$ & $\begin{array}{l}\text { South Pacific } \\
23^{\circ} 42.289 \mathrm{~S}, 131^{\circ} 12.744 \mathrm{~W}\end{array}$ & n.a. & $\begin{array}{l}\text { KF557519 } X * \\
\ldots \ldots \text { KX }\end{array}$ & n.a. \\
\hline PAC26 & $\begin{array}{l}\text { Collodaria } \\
\text { (colony) }\end{array}$ & $\begin{array}{l}\text { South Pacific } \\
23^{\circ} 42.289 \mathrm{~S}, 131^{\circ} 12.744 \mathrm{~W}\end{array}$ & n.a. & $\begin{array}{l}\text { KF557520** } \\
\text { Xxxxx }\end{array}$ & n.a. \\
\hline PAC27 & $\begin{array}{l}\text { Collodaria } \\
\text { (colony) }\end{array}$ & $\begin{array}{l}\text { South Pacific } \\
23^{\circ} 42.289 \mathrm{~S}, 131^{\circ} 12.744 \mathrm{~W}\end{array}$ & n.a. & $\begin{array}{l}\text { KF557521 Xx } \\
\text { XXXXX }\end{array}$ & n.a. \\
\hline SES47 & $\begin{array}{l}\text { Collodaria } \\
\text { (colony) }\end{array}$ & $\begin{array}{l}\text { Sesoko, Japan } \\
26^{\circ} 37^{\prime} 20 \mathrm{~N}, 127^{\circ} 52^{\prime} 15 \mathrm{E}\end{array}$ & n.a. & $\begin{array}{l}\text { KF557502 } ¥ x \\
\text { xxxxx }\end{array}$ & $\begin{array}{l}\text { KF557546 XXXX } \\
\text { XXX }\end{array}$ \\
\hline SES19 & Spumellaria & $\begin{array}{l}\text { Sesoko, Japan } \\
26^{\circ} 37^{\prime} 20 \mathrm{~N}, 127^{\circ} 52^{\prime} 15 \mathrm{E}\end{array}$ & n.a. & $\begin{array}{l}\text { KF557501** } \\
\text { XXxxx }\end{array}$ & n.a. \\
\hline $\begin{array}{c}\text { SES28 } \\
\end{array}$ & Nassellaria & $\begin{array}{l}\text { Sesoko, Japan } \\
26^{\circ} 37^{\prime} 20 \mathrm{~N}, 127^{\circ} 52^{\prime} 15 \mathrm{E}\end{array}$ & n.a. & n.a. & $\begin{array}{l}\text { KF557545 \#XXK } \\
\text { XXX }\end{array}$ \\
\hline Vil 210 & Spumellaria? & $\begin{array}{l}\text { Villefranche-sur-Mer, France } \\
43^{\circ} 41^{\prime} 10 \mathrm{~N}, 7^{\circ} 18^{\prime} 50 \mathrm{E}\end{array}$ & n.a. & $\begin{array}{l}\text { KF557522xx } \\
\text { xxxxx }\end{array}$ & n.a. \\
\hline Vil 217 & Spumellaria & $\begin{array}{l}\text { Villefranche-sur-Mer, France } \\
43^{\circ} 41^{\prime} 10 \mathrm{~N}, 7^{\circ} 18^{\prime} 50 \mathrm{E}\end{array}$ & n.a. & $\begin{array}{l}\underline{\text { KF557523xx }} \\
\text { xxxxx }\end{array}$ & n.a. \\
\hline Vil 219 & Spumellaria & $\begin{array}{l}\text { Villefranche-sur-Mer, France } \\
43^{\circ} 41^{\prime} 10 \mathrm{~N}, 7^{\circ} 18^{\prime} 50 \mathrm{E}\end{array}$ & n.a. & $\begin{array}{l}\text { KF557524XX } \\
\text { XXX** }\end{array}$ & n.a. \\
\hline Vil 231 & Spumellaria & $\begin{array}{l}\text { Villefranche-sur-Mer, France } \\
43^{\circ} 41^{\prime} 10 \mathrm{~N}, 7^{\circ} 18^{\prime} 50 \mathrm{E}\end{array}$ & n.a. & $\begin{array}{l}\text { KF557525X* } \\
\underset{x x x x x}{ }\end{array}$ & n.a. \\
\hline \multicolumn{6}{|l|}{$\begin{array}{l}\text { Culture } \\
\text { strains }\end{array}$} \\
\hline SES46 & $\begin{array}{l}\text { Collodaria } \\
\text { (Collozoum }\end{array}$ & $\begin{array}{l}\text { Sesoko, Japan } \\
26^{\circ} 37^{\prime} 20 \mathrm{~N}, 127^{\circ} 52^{\prime} 15 \mathrm{E}\end{array}$ & RCC3378 & $\begin{array}{l}\text { KF557500 } x x \\
\text { xXXXx }\end{array}$ & $\begin{array}{l}\text { KF557526xXXx } \\
\text { *X* }\end{array}$ \\
\hline & colony) & & $\underline{\mathrm{RCC} 3379}$ & $\underline{\text { KF557499 }}$ & n.a. \\
\hline SES46B & $\begin{array}{l}\text { Collodaria } \\
\text { (Collozoum } \\
\text { eolony) }\end{array}$ & $\begin{array}{l}\text { Sesoko, Japan } \\
26^{\circ} 37^{\prime} 20 \mathrm{~N}, 127^{\circ} 52^{\prime} 15 \mathrm{E}\end{array}$ & RCC3379 & XXXXXXXY & n.a. \\
\hline VFPO14-8 & $\begin{array}{l}\text { Collodaria } \\
\text { (Collozoum }\end{array}$ & $\begin{array}{l}\text { Villefranche-sur-Mer, France } \\
43^{\circ} 41^{\prime} 10 \mathrm{~N}, 7^{\circ} 18^{\prime} 50 \mathrm{E}\end{array}$ & RCC3380 & 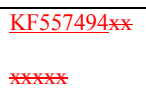 & $\begin{array}{l}\text { KF557530 XXXX } \\
\text { *KX }\end{array}$ \\
\hline
\end{tabular}




\begin{tabular}{|c|c|c|c|c|c|}
\hline & \multirow[t]{2}{*}{ colony) } & & $\underline{\mathrm{RCC} 3381}$ & KF557495 & KF557531 \\
\hline & & & RCC3382 & KF557496 & KF557532 \\
\hline VFPO14-13 & $\begin{array}{l}\text { Collodaria } \\
\text { (Collozoum } \\
\text { eolony) }\end{array}$ & $\begin{array}{l}\text { Villefranche-sur-Mer, France } \\
4^{\circ} 41^{\prime} 10 \mathrm{~N}, 7^{\circ} 18^{\prime} 50 \mathrm{E}\end{array}$ & RCC3381 & XXXXXXX & XXXXXXXX \\
\hline VFPO14-14 & $\begin{array}{l}\text { Collodaria } \\
\text { (Collozoum } \\
\text { colony) }\end{array}$ & $\begin{array}{l}\text { Villefranche-sur-Mer, France } \\
43^{\circ} 41^{\prime} 10 \mathrm{~N}, 7^{\circ} 18^{\prime} 50 \mathrm{E}\end{array}$ & RCC3382 & XXXXXXX & XXXXXXXX \\
\hline VFPO2- & Spumellaria & $\begin{array}{l}\text { Villefranche-sur-Mer, France } \\
43^{\circ} 41^{\prime} 10 \mathrm{~N}, 7^{\circ} 18^{\prime} 50 \mathrm{E}\end{array}$ & RCC3383 & 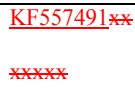 & 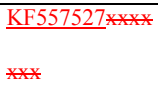 \\
\hline & & & RCC3384 & n.a. & KF557528 \\
\hline VFPO2-2 & Spumellaria & $\begin{array}{l}\text { Villefranche-sur-Mer, France } \\
43^{\circ} 41^{\prime} 10 \mathrm{~N}, 7^{\circ} 18^{\prime} 50 \mathrm{E}\end{array}$ & RCC3384 & ก.a. & XXXXXXXX \\
\hline VFPO5 & Spumellaria & $\begin{array}{l}\text { Villefranche-sur-Mer, France } \\
43^{\circ} 41^{\prime} 10 \mathrm{~N}, 7^{\circ} 18^{\prime} 50 \mathrm{E}\end{array}$ & RCC3385 & $\begin{array}{l}\underline{\text { KF557492 Xx }} \\
\text { xxxxx }\end{array}$ & n.a. \\
\hline VFPO22- & Spumellaria & $\begin{array}{l}\text { Villefranche-sur-Mer, France } \\
43^{\circ} 41^{\prime} 10 \mathrm{~N}, 7^{\circ} 18^{\prime} 50 \mathrm{E}\end{array}$ & RCC3386 & $\begin{array}{l}\text { KF557497** } \\
\text { Xxxxx }\end{array}$ & n.a. \\
\hline VFR1-1 & Spumellaria & $\begin{array}{l}\text { Villefranche-sur-Mer, France } \\
43^{\circ} 41^{\prime} 10 \mathrm{~N}, 7^{\circ} 18^{\prime} 50 \mathrm{E}\end{array}$ & RCC3387 & $\begin{array}{l}\text { KF557498XX } \\
\text { XXXXX }\end{array}$ & 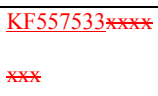 \\
\hline VFPO10 & Nassellaria & $\begin{array}{l}\text { Villefranche-sur-Mer, France } \\
43^{\circ} 41^{\prime} 10 \mathrm{~N}, 7^{\circ} 18^{\prime} 50 \mathrm{E}\end{array}$ & RCC3388 & $\begin{array}{l}\text { KF557493xx } \\
\text { xxxxx }\end{array}$ & $\begin{array}{l}\text { KF557529XXXX } \\
\text { xxx }\end{array}$ \\
\hline
\end{tabular}

1 
1 Table 2. Kofoidian plate tabulation of Brandtodinium and related genera

\begin{tabular}{|c|c|}
\hline Scrippsiella & Po, X, 4', 3a, 6-7'’, 6c, 4-7s, 5'’, 2'”’ \\
\hline Calciodinellum & Po, X, 4', 3a, 7', 6c, 5s, 5'’, 2',', \\
\hline Bysmatrum & Po, X, 4', 3a, 7', 6c, 4-5s, 5'"', 2'", \\
\hline Pentapharsodinium & Рo, X, 4', 3a, 7’', 5c, 4s, 5'”, 2','” \\
\hline Ensiculifera & Po, X, 4', 3a, 7', 5c, 5s, 5'’, 2','’ \\
\hline Brandtodinium & Po, X, 4', 3a, 7', 5c, 4s, 5',', 1','’ \\
\hline
\end{tabular}

2 
Figure captions

3 Figure 1. Light micrographs of Brandtodinium nutriculum gen. nov., comb. nov..

4 (arrow indicates large pyrenoid). A, B. Ventral view of the cell showing the large

5 nucleus in the central portion of the cell. C. Lateral (slightly antapical) view of the

6 cell. D. Dorsal view of the cell. Scale bars $=5 \mu \mathrm{m}$.

7

8 Figure 2. SEM micrographs of Brandtodinium nutriculum gen. nov., comb. nov..

9 (enumeration of plates follows the Kofoidian tabulation system). A. Ventral view of a

10 cell (flagella lost during fixation). B. Detail of the sulcal region. C. Dorsal view. D.

11 Apical view. E. Antapical view. Scale bars $=2 \mu \mathrm{m}$.

12

13 Figure 3. Schematic representation of plate patterns of Brandtodinium nutriculum gen.

14 nov., comb. nov. (enumeration of plates follows the Kofoidian tabulation system). A.

15 Ventral view (generalized). B. Dorsal view (generalized). C. Apical view

16 (generalized). D. Antapical view (generalized).

17

18 Figure 4. SSU rDNA phylogenetic tree inferred by Maximum Likelihood (ML)

19 analysis. 650- $\underline{652}$ unambiguously aligned positions were considered from an

20 alignment of 57 sequences, including Brandtodinium gen. nov.. Sequences obtained in

21 this study are indicated in bold (followed by the type of host from which the sequence

22 was obtained and the number of holobiont specimens or culture strains in

23 parentheses). The tree was rooted with Suessiales (Symbiodinium spp. and

24 Pelagodinium béii) as the outgroup. Branch lengths are drawn to scale, with the scale

25 bar indicating the number of nucleotide substitutions per site. Numbers on branches 
1 are statistical support values for the clusters to the right of them (first: ML bootstrap

2 support values, values under 0.5 are not shown; second: Bayesian posterior

3 probabilities, values under 0.5 are not shown; black dots at nodes represent a

$4 \quad$ statistical support of 1 for both methods).

6 Figure 5. LSU rDNA phylogenetic tree inferred by Maximum Likelihood (ML)

7 analysis. 675 unambiguously aligned positions were considered from an alignment of

848 sequences, including Brandtodinium gen. nov.. Sequences obtained in this study

9 are indicated in bold (followed by the type of host from which the sequence was

10 obtained and the number of holobiont specimens or culture strains in parentheses).

11 The tree was rooted with Suessiales (Symbiodinium spp. and Pelagodinium beii) as

12 the outgroup. Branch lengths are drawn to scale, with the scale bar indicating the

13 number of nucleotide substitutions per site. Numbers on branches are statistical

14 support values for the clusters to the right of them (first: ML bootstrap support values,

15 values under 0.5 are not shown; second: Bayesian posterior probabilities, values under

160.5 are not shown; black dots at nodes represent a statistical support of 1 for both

17 methods).

18

Supplementary Figure 1. LM images of host cells from which uncultured symbiont (holobiont) sequences were retrieved.

Supplementary Figure 2. LM images of host cells from which cultures were isolated. 
1 from an alignment of 59 sequences, including Bysmatrum. The tree was rooted with

Suessiales (Symbiodinium spp. and Pelagodinium béii) as the outgroup. Branch

lengths are drawn to scale, with the scale bar indicating the number of nucleotide

substitutions per site. Numbers on branches are statistical support values for the

not shown; second: Bayesian posterior probabilities, values under 0.5 are not shown;

black dots at nodes represent a statistical support of 1 for both methods).

8 


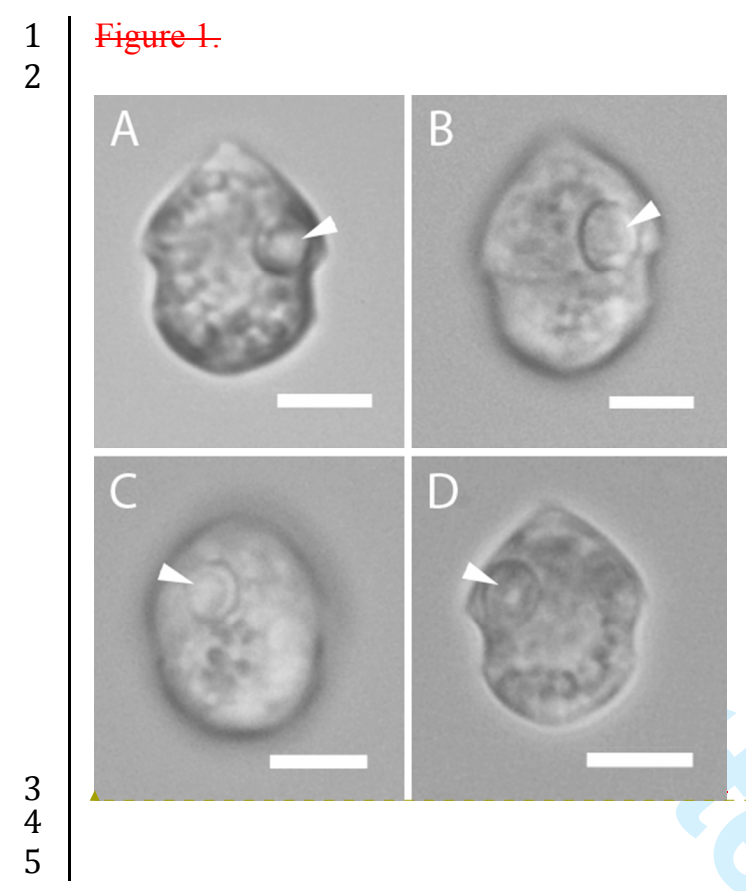

Formatted: Font: (Default) Arial 


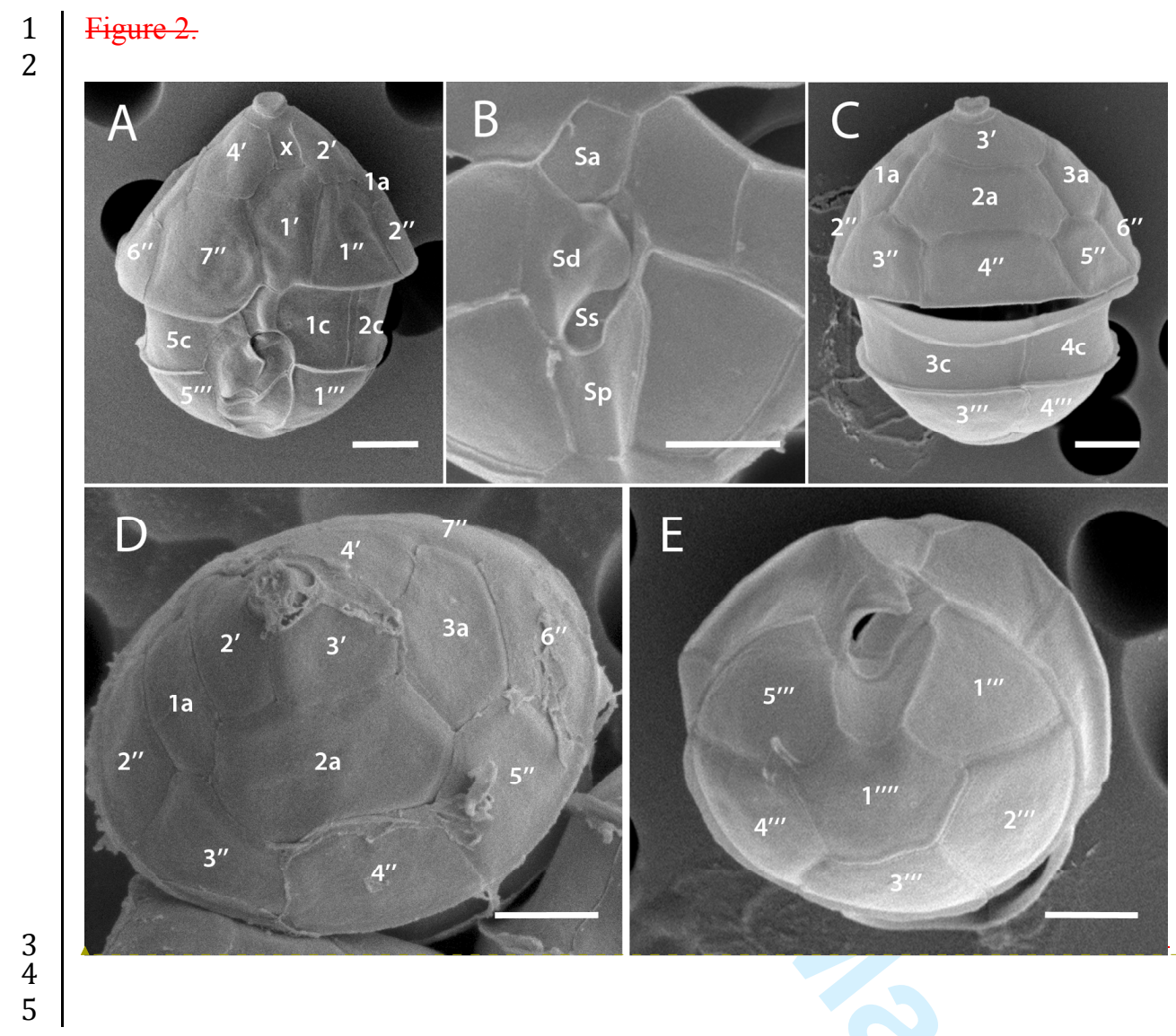

Formatted: Font: (Default) Arial 


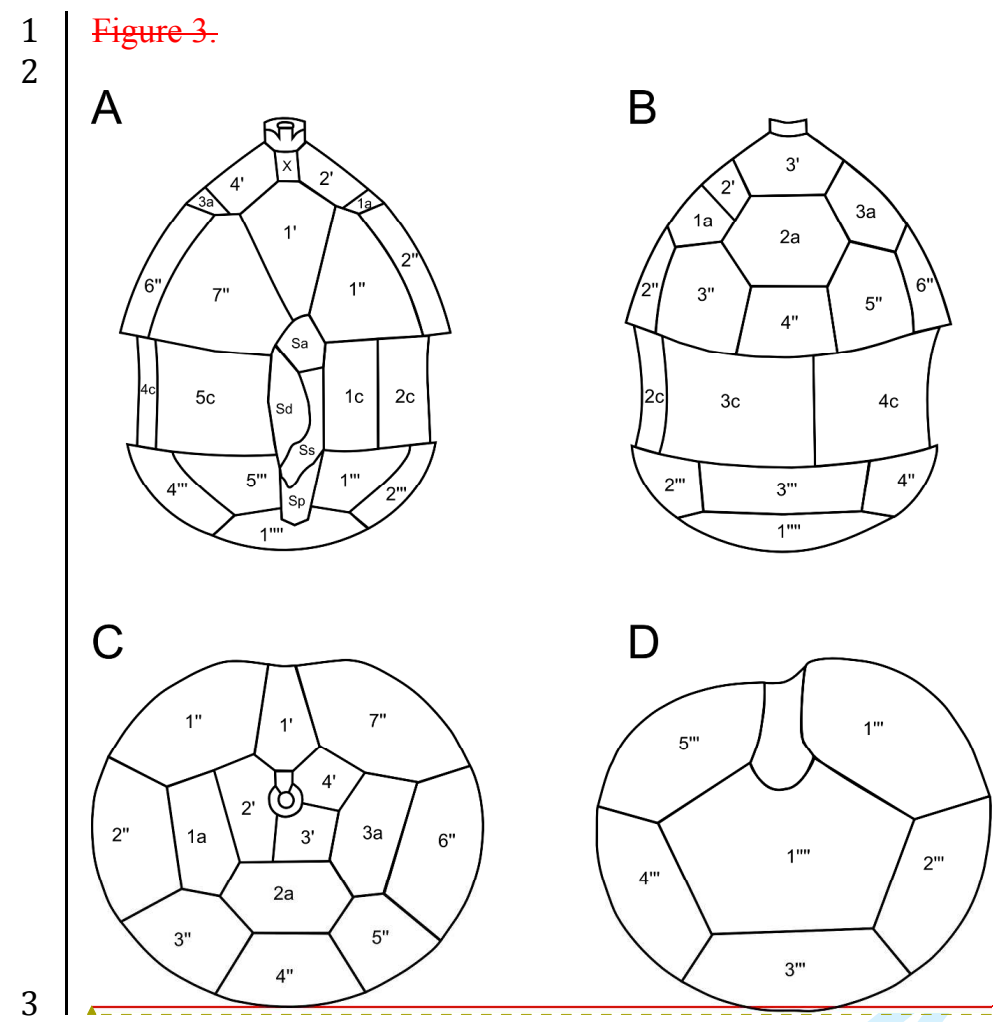

Formatted: Line spacing: single

Formatted: Font: (Default) Arial 


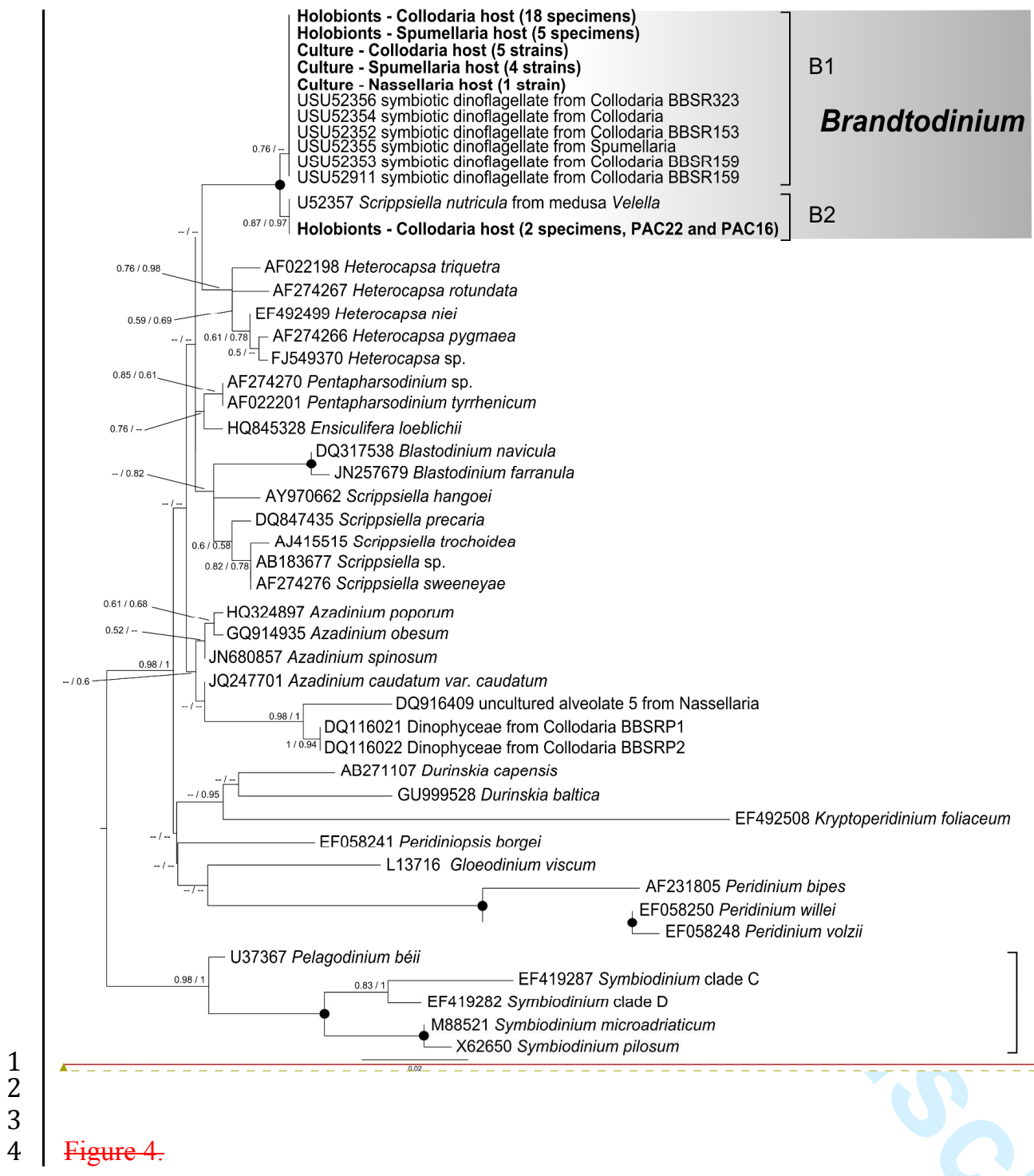




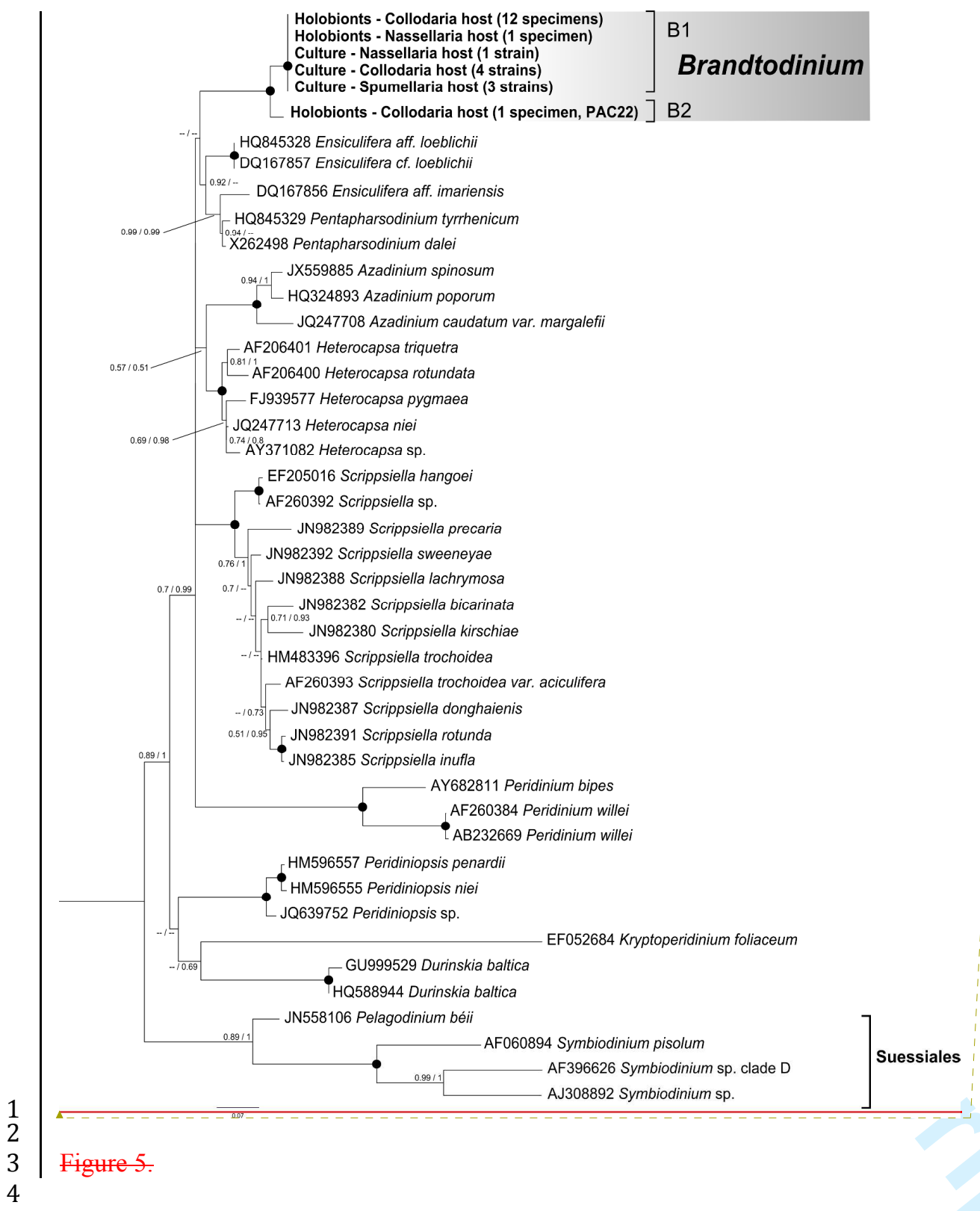

Formatted: Font: (Default) Arial 

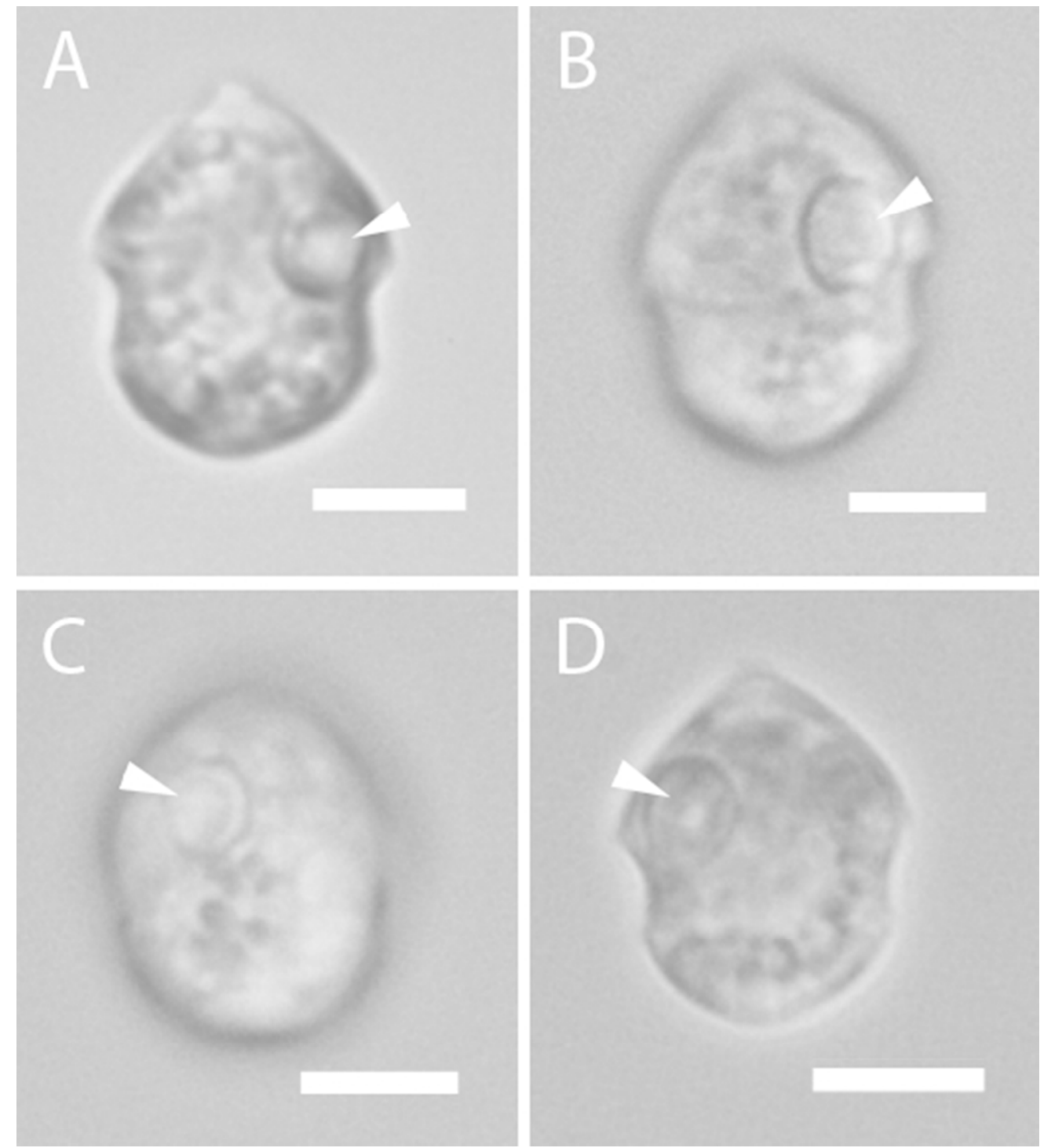

Figure 1. Light micrographs of Brandtodinium nutriculum gen. nov., comb. nov.. (arrow indicates large pyrenoid). A, B. Ventral view of the cell showing the large nucleus in the central portion of the cell. C. Lateral (slightly antapical) view of the cell. D. Dorsal view of the cell. Scale bars $=5 \mu \mathrm{m}$. $44 \times 49 \mathrm{~mm}(300 \times 300 \mathrm{DPI})$ 

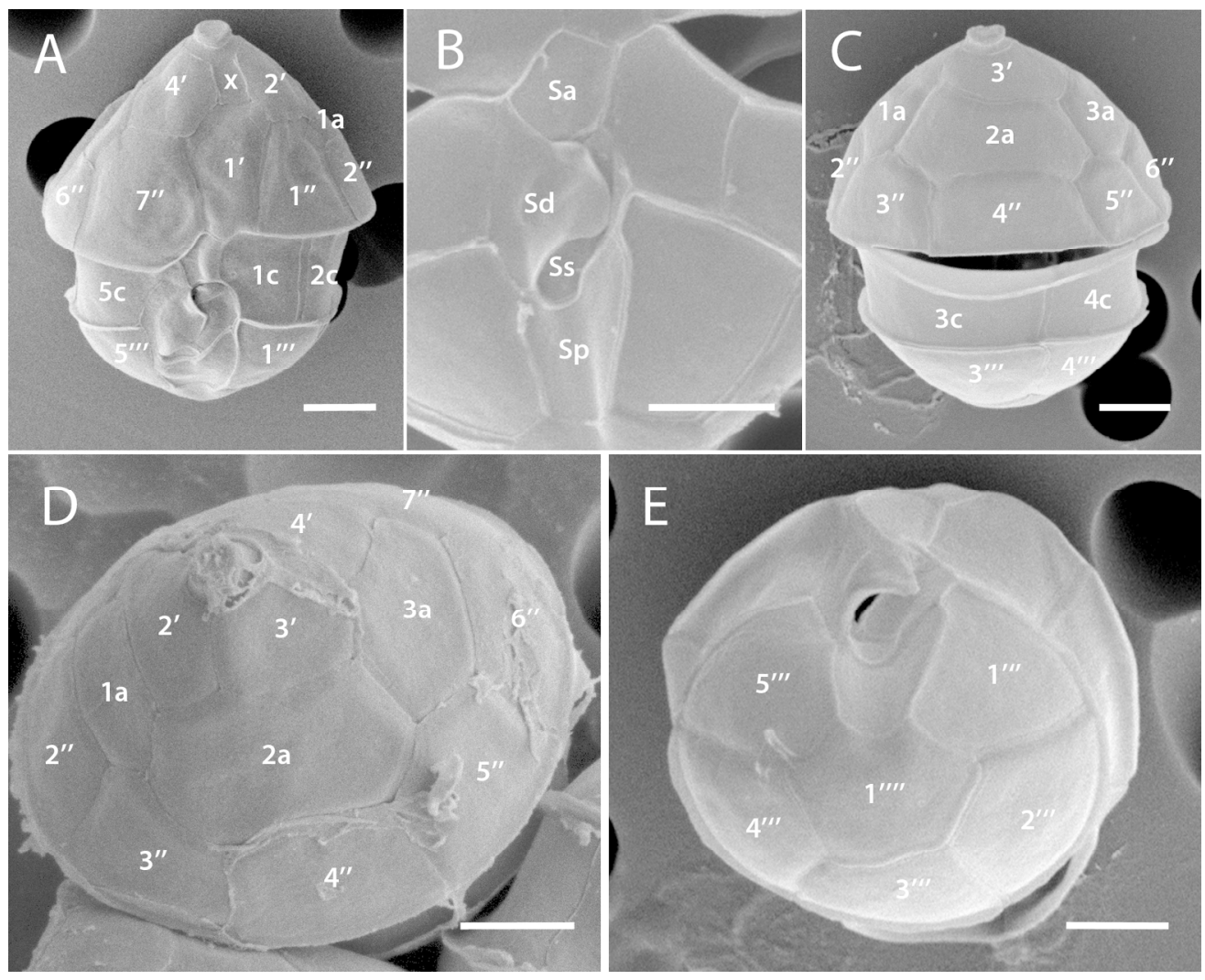

Figure 2. SEM micrographs of Brandtodinium nutriculum gen. nov., comb. nov.. (enumeration of plates follows the Kofoidian tabulation system). A. Ventral view of a cell (flagella lost during fixation). B. Detail of the sulcal region. C. Dorsal view. D. Apical view. E. Antapical view. Scale bars $=2 \mu \mathrm{m}$. $175 \times 140 \mathrm{~mm}(300 \times 300 \mathrm{DPI})$ 
A

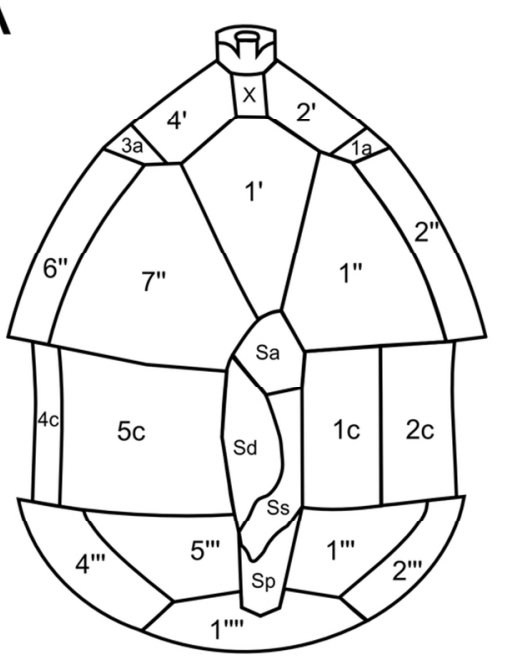

$\mathrm{C}$

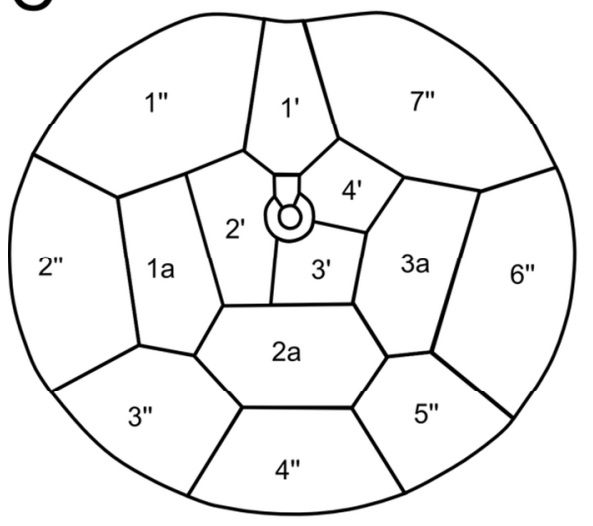

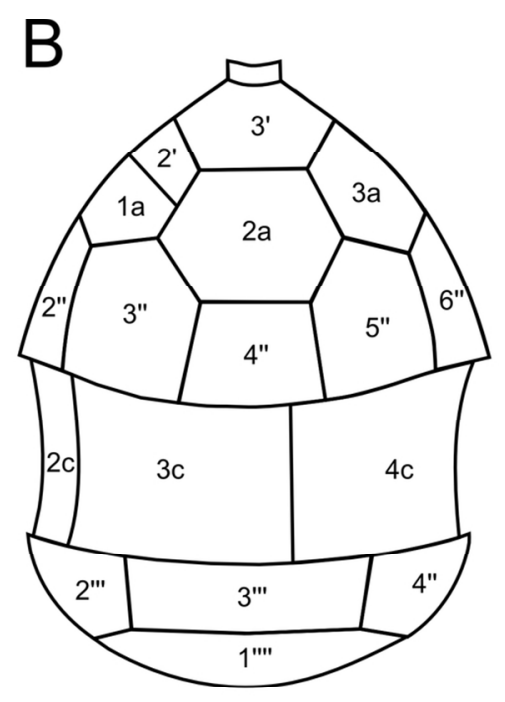

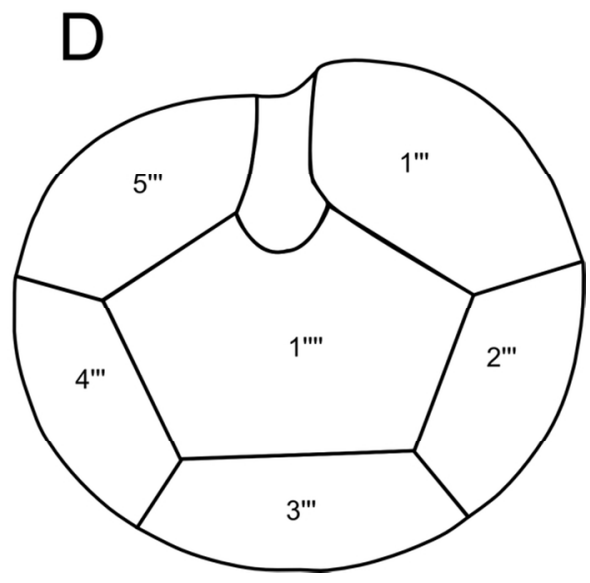

Figure 3. Schematic representation of plate patterns of Brandtodinium nutriculum gen. nov., comb. nov. (enumeration of plates follows the Kofoidian tabulation system). A. Ventral view (generalized). B. Dorsal view (generalized). C. Apical view (generalized). D. Antapical view (generalized). $111 \times 114 \mathrm{~mm}$ (300 x 300 DPI) 


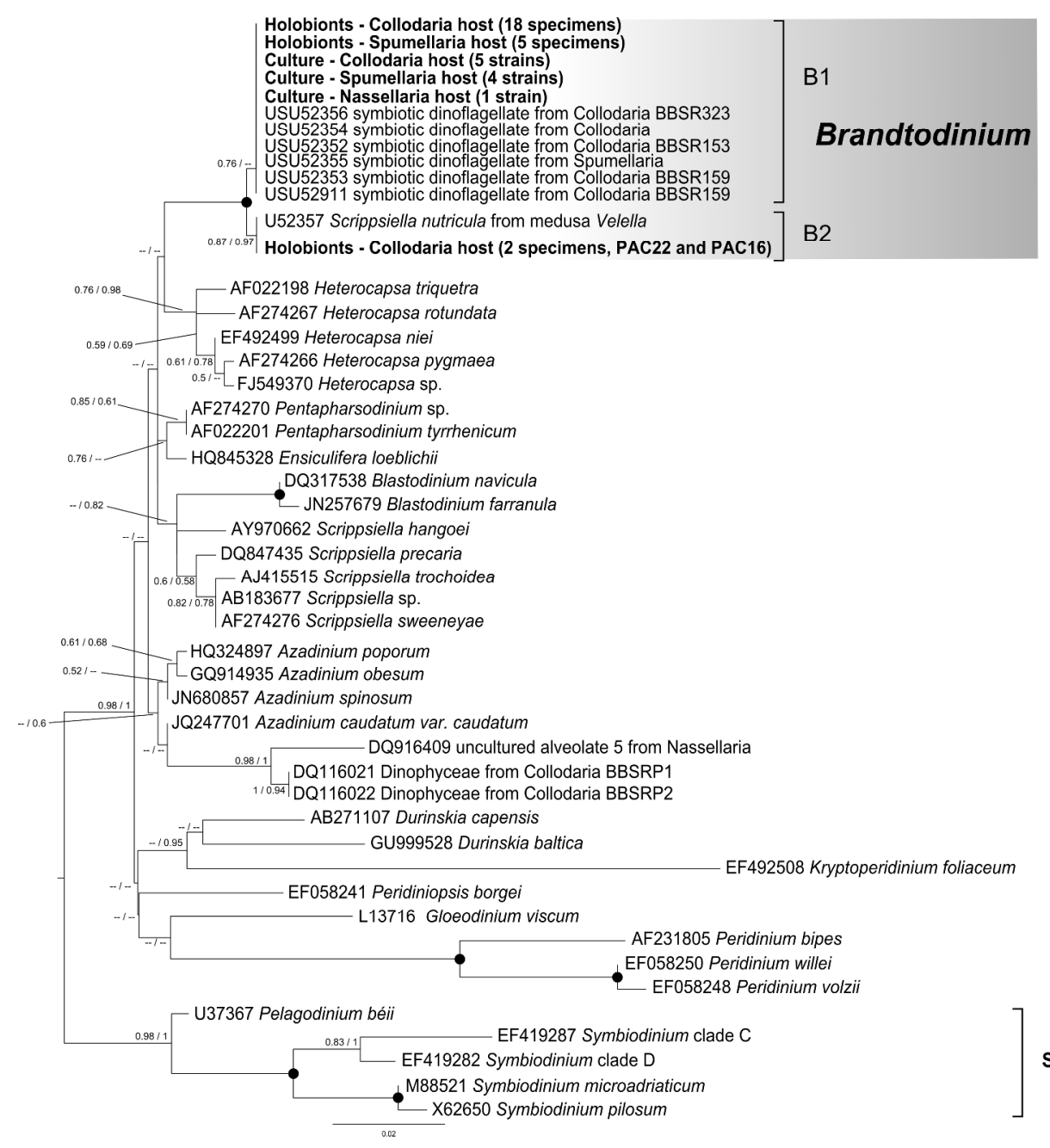

Figure 4. SSU rDNA phylogenetic tree inferred by Maximum Likelihood (ML) analysis. 652 unambiguously aligned positions were considered from an alignment of 57 sequences, including Brandtodinium gen. nov..

Sequences obtained in this study are indicated in bold (followed by the type of host from which the sequence was obtained and the number of holobiont specimens or culture strains in parentheses). The tree was rooted with Suessiales (Symbiodinium spp. and Pelagodinium béii) as the outgroup. Branch lengths are drawn to scale, with the scale bar indicating the number of nucleotide substitutions per site. Numbers on branches are statistical support values for the clusters to the right of them (first: ML bootstrap support values, values under 0.5 are not shown; second: Bayesian posterior probabilities, values under 0.5 are not shown; black dots at nodes represent a statistical support of 1 for both methods). 


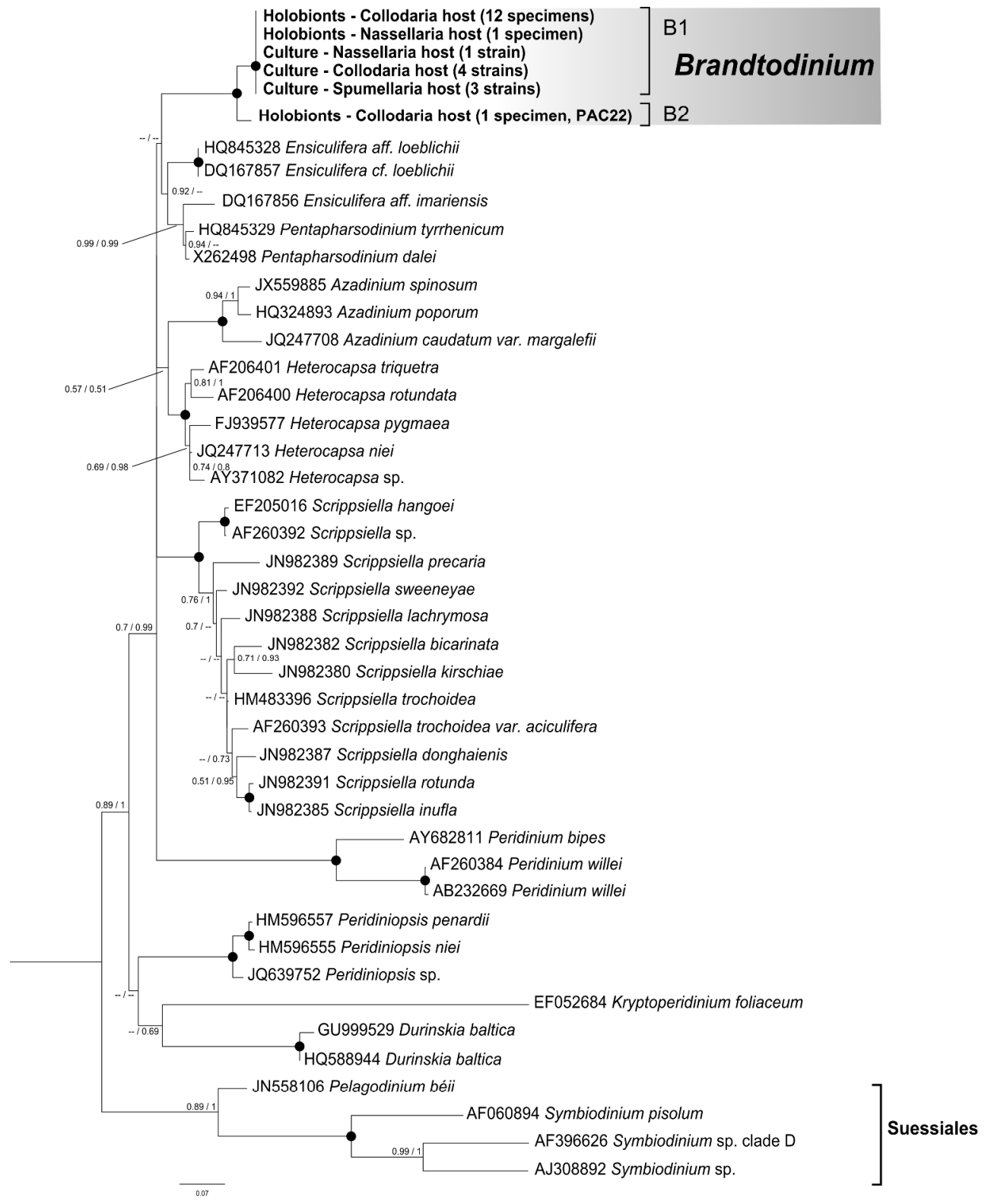

Figure 5. LSU rDNA phylogenetic tree inferred by Maximum Likelihood (ML) analysis. 675 unambiguously aligned positions were considered from an alignment of 48 sequences, including Brandtodinium gen. nov..

Sequences obtained in this study are indicated in bold (followed by the type of host from which the sequence was obtained and the number of holobiont specimens or culture strains in parentheses). The tree was rooted with Suessiales (Symbiodinium spp. and Pelagodinium beii) as the outgroup. Branch lengths are drawn to scale, with the scale bar indicating the number of nucleotide substitutions per site. Numbers on branches are statistical support values for the clusters to the right of them (first: ML bootstrap support values, values under 0.5 are not shown; second: Bayesian posterior probabilities, values under 0.5 are not shown; black dots at nodes represent a statistical support of 1 for both methods). $301 \times 370 \mathrm{~mm}(299 \times 299 \mathrm{DPI})$ 


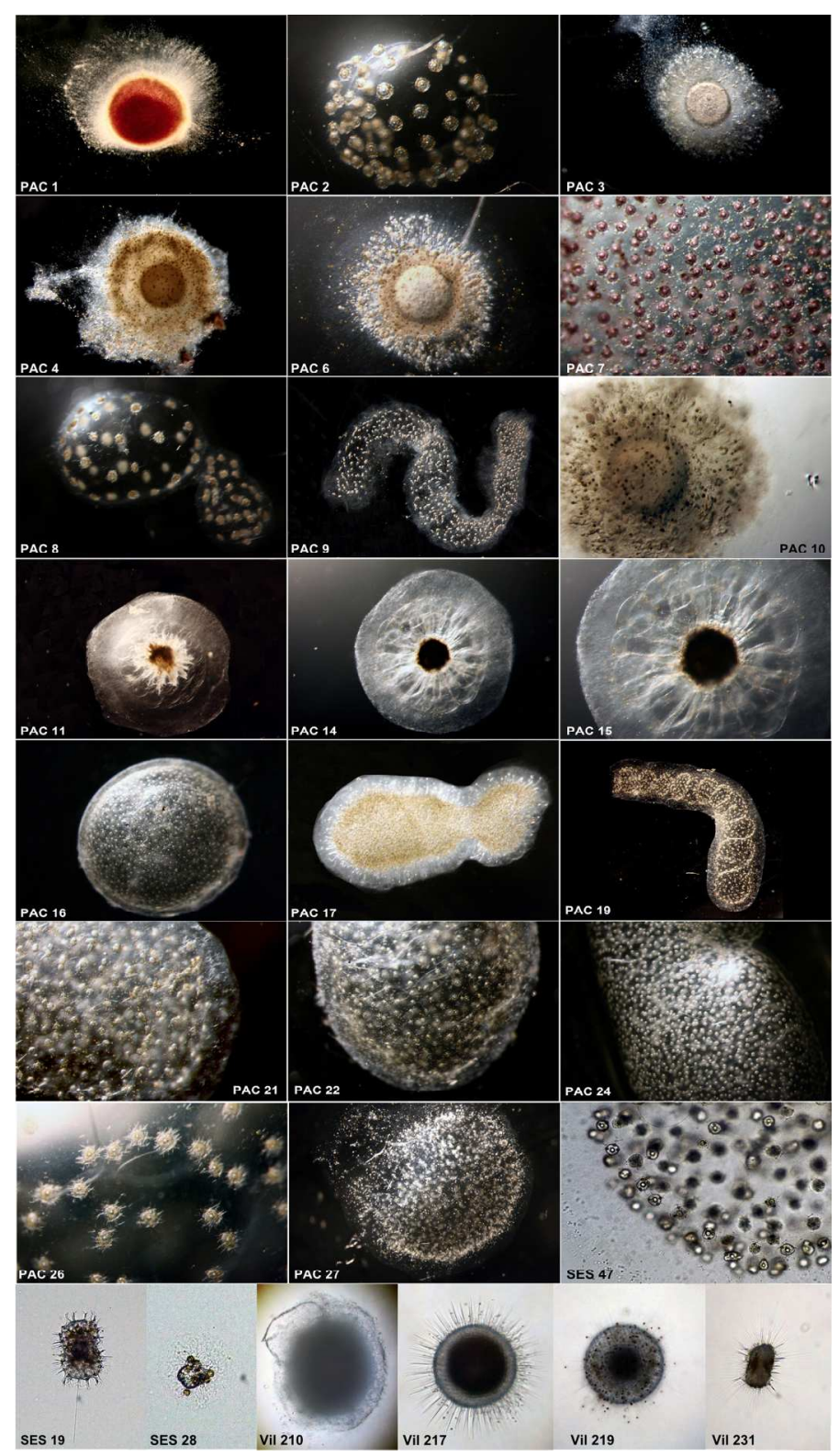

Supplementary Figure 1. LM images of host cells from which uncultured symbiont (holobiont) sequences were retrieved. $165 \times 291 \mathrm{~mm}(300 \times 300 \mathrm{DPI})$ 


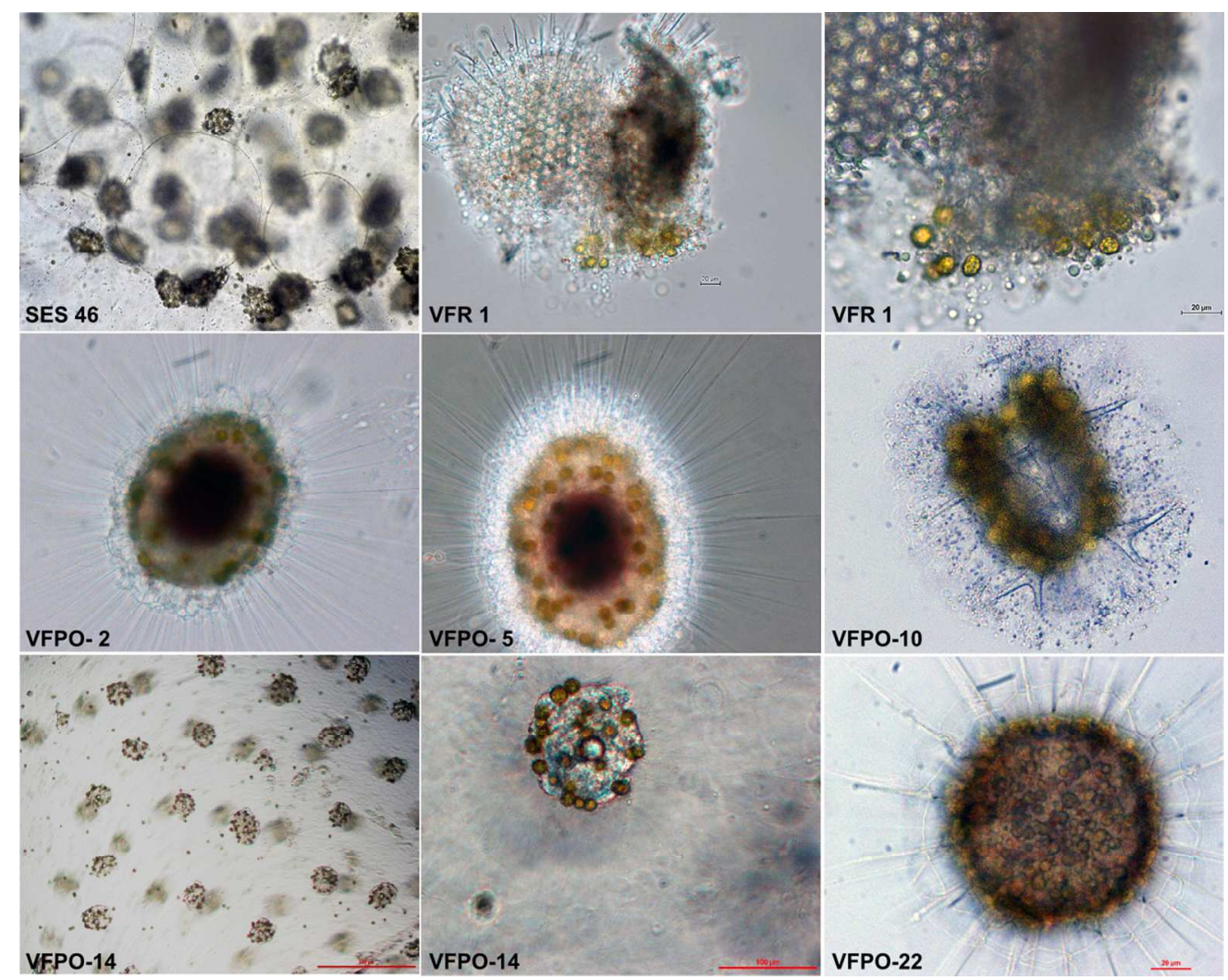

Supplementary Figure 2. LM images of host cells from which cultures were isolated. $170 \times 136 \mathrm{~mm}(300 \times 300 \mathrm{DPI})$ 


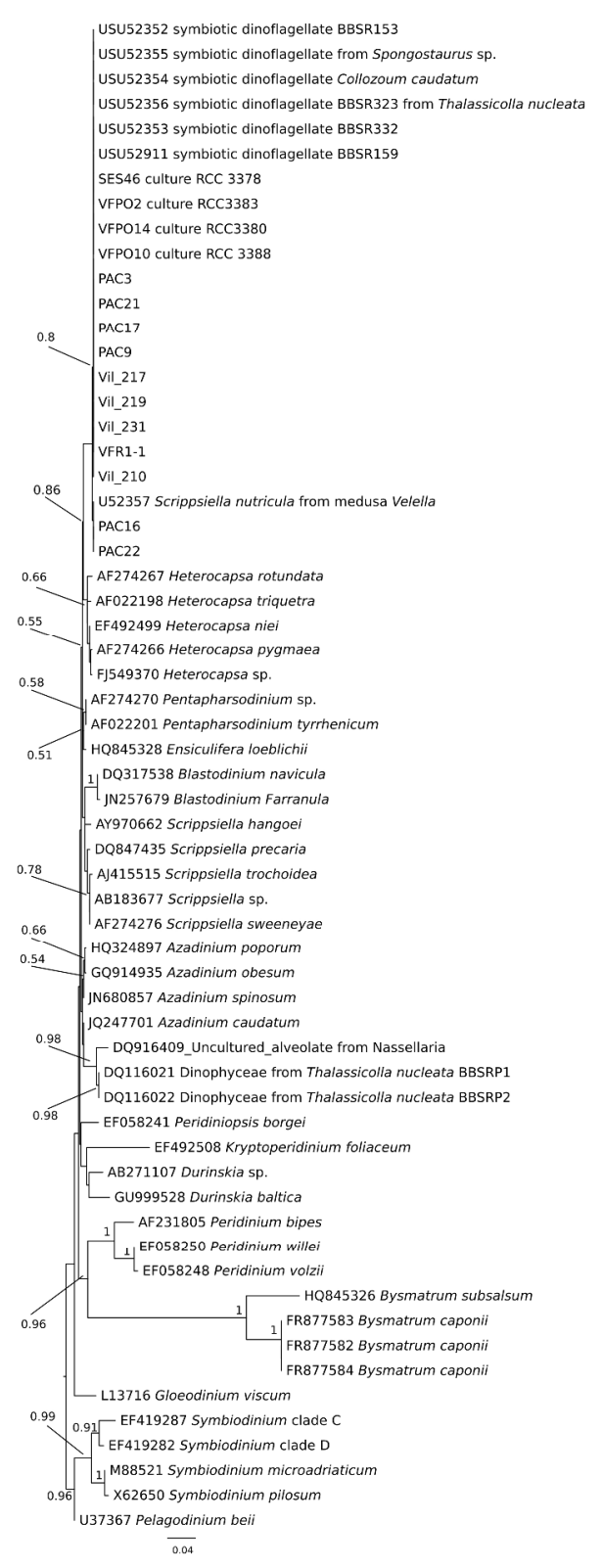

Supplementary Figure 3. SSU rDNA phylogenetic tree inferred by Maximum Likelihood (ML) analysis. 652 unambiguously aligned positions were considered from an alignment of 59 sequences, including Bysmatrum. The tree was rooted with Suessiales (Symbiodinium spp. and Pelagodinium béii) as the outgroup. Branch lengths are drawn to scale, with the scale bar indicating the number of nucleotide substitutions per site. Numbers on branches are ML bootstrap support values (values under 0.5 are not shown). $163 \times 440 \mathrm{~mm}$ (299 x 299 DPI) 